\title{
KONSEP NAZHIR WAKAF PROFESIONAL DAN IMPLEMENTASINYA DI LEMBAGA WAKAF NU DAN MUHAMMADIYAH
}

\author{
Oleh:
}

\section{Ali Khosim dan Busro}

UIN Sunan Gunung Djati Bandung, Jawa Barat, Indonesia

Email:ali.khosim12@gmail.com; busro@uinsgd.ac.id

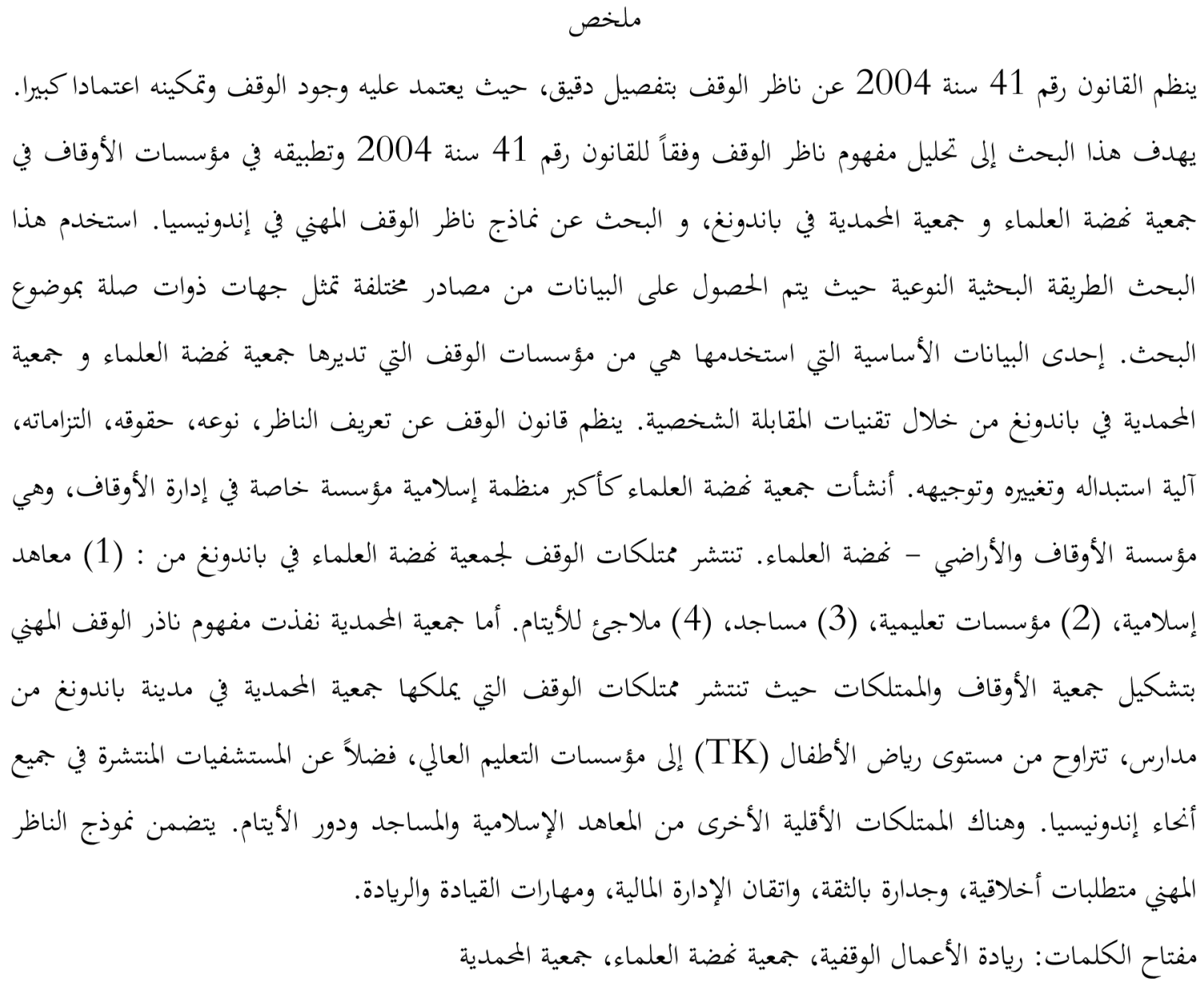

Abstract

This study aims to analyze the concept of Nazhir waqf according to Law Number 41 of 2004 and its implementation in the waqf organizations of NU and Muhammadiyah Islamic Cities in Bandung, as well as looking for Nazi professional waqf models in Indonesia. The research method that I use is qualitative. The researcher seeks to obtain data from various sources that are representative and relevant to the object of study under study. One of the primary data that I use is from waqf institutions managed by NU and Muhammadiyah City of Bandung administrators through interview techniques.. In an effort to implement the concept of Nazir waqf professional which refers to the Law of Representatives in Indonesia, NU as the largest Islamic community organization formed an institution that deals specifically with representatives and land, namely Waqf and Land Agency (NU LWP). The waqf assets owned by NU in Bandung are spread in the form of: (1) Islamic boarding schools, (2) educational institutions, (3), mosques, (4) orphanages. Whereas Muhammadiyah in implementing the concept of professional nazhir waqf formed the Assembly of Endowments and 
Independence (MWK). The waqf assets owned by Muhammadiyah in the city of Bandung are spread in the form of schools, ranging from the level of kindergarten (TK) to tertiary institutions, as well as hospitals spread throughout Indonesia. Another minority are Islamic boarding schools, mosques and orphanages. The Nazir professional endowments model includes moral requirements, trustworthiness, mastering administrative and financial management and having leadership and entrepreneurship skills.

Keyword: waqf Muhamaddiyah and NU.

\begin{abstract}
Abstrak
Penelitian ini bertujuan menganalisis konsep nazhir wakaf menurut undang-undang nomor 41 tahun 2004 dan implementasinya di lembaga wakaf ormas Islam NU dan Muhammadiyah Kota Bandung, serta mencari model nazhir wakaf profesional di Indonesia. Metode penelitian yang penulis gunakan adalah kualitatif. Hasil penelitian menunjukan bahwa konsep nazhir wakaf telah diatur dalam Undang-undang No. 41 Tahun 2004 tentang wakaf dengan sangat rinci, mulai dari pengertian, jenis nazhir, hak dan kewajiban nazhir, mekanisme pemberhentian dan pergantian nazhir serta pembinaan nazhir. Dalam upaya mengimplementasikan konsep nazhir wakaf profesional yang mengacu pada Undang-undang perwakafan di Indonesia, NU sebagai organisasi masyarakat Islam terbesar membentuk lembaga yang menangani khusus tentang perwakafan dan pertanahan yaitu Lembaga Wakaf dan Pertanahan (LWP NU). Adapun Aset-aset wakaf yang dimiliki oleh NU kota Bandung tersebar dalam bentuk yaitu: (1) Pondok pesantren, (2) Lembaga pendidikan, (3), Masjid, (4) Panti asuhan. Sedangkan Muhammadiyah dalam mengimplementasikan konsep nazhir wakaf profesional membentuk Majelis Wakaf dan Kehartabendaan (MWK). Adapun Asetaset wakaf yang dimiliki oleh Muhammadiyah kota Bandung tersebar dalam bentuk sekolah, mulai dari tingkat taman kanak-kanak (TK) hingga perguruan tinggi, serta rumah sakit yang tersebar di seluruh Indonesia. Sebagian kecil lainnya adalah pondok pesantren, masjid dan panti asuhan. Adapun model nazhir wakaf profesional yaitu meliputi persyaratan moral, amanah, menguasai ilmu manjemen administrasi dan keuangan serta memiliki skill leadership dan enterpreneurship.
\end{abstract}

Kata kunci: Wakaf Muhammadiyah dan NU.

\section{A. Pendahuluan}

Wakaf merupakan salah satu ibadah sosial yang sangat penting dalam ajaran Islam serta sangat erat kaitannya dengan kesejahteraan umat. Wakaf juga mempunyai kekuatan ekonomi yang luar biasa jika pemanfaatan dan pengelolaannya dilakukan secara maksimal. Karena posisi wakaf yang demikianlah maka wakaf diatur secara khusus dalam peraturan perundang-undangan di Indonesia.

Ditinjau dari sisi definisinya, pada dasarnya pengertian wakaf sangat variatif. Sebagian ulama berpendapat bahwa perintah wakaf merupakan bagian dari perintah untuk melakukan al-khair (kebaikan). Sebagaimana yang termaktub dalam ayat berikut:

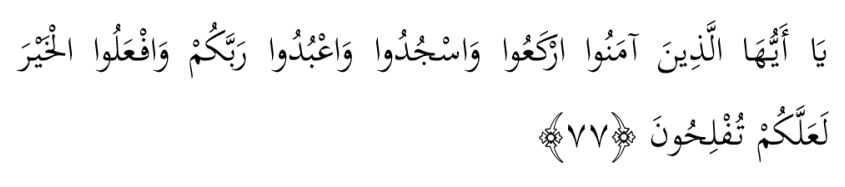

"Hai orang-orang yang beriman, rukuklah kamu, sujudlah kamu, sembahlah Tuhanmu dan perbuatlah kebajikan, supaya kamu mendapat kemenangan." ${ }^{1}$

Taqiyudin Abi Bakar Ibnu Muhammad alHusaini al-Dimasqi menafsirkan bahwa perintah

\footnotetext{
${ }^{1}$ QS. Al-Hajj (22): 77
} 
untuk melakukan al-khair berarti perintah untuk melakukan wakaf. ${ }^{2}$ Penafsiran menurut al-Dimasqi tersebut relevan dengan firman Allah tentang wasiat.

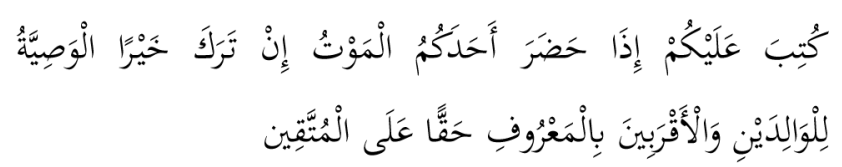

"Diwajibkan atas kamu, apabila seorang di antara kamu kedatangan (tanda-tanda) maut, jika ia meninggalkan harta yang banyak, berwasiat untuk ibu-bapak dan karib kerabatnya secara ma'ruf, (ini adalah) kewajiban atas orang-orang yang bertakwa."

Wakaf juga dalam beberapa term disebutkan dengan sedekah jariah (shodaqoh jariyah). Dalam perspektif ini, wakaf dianggap sebagai bagian dari sedekah. Sebagaimana termaktub dalam hadis:

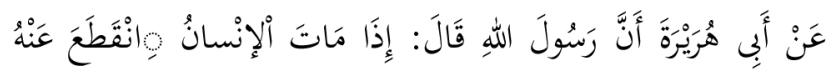

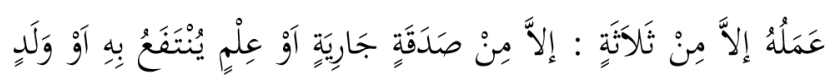
4

"(Seluruh pahala) perbuatan manusia terputus apabila telah meninggal, kecuali tiga perkara yaitu sedekah jariyah, ilmu yang bermanfaat dan anak saleh yang mendoakannya. (HR Muslim, Abu Dawud, at-Tirmidzi, an-Nasa'i dan Ahmad )"

Selain sedekah jariah, wakaf secara bahasa disebut pula sebagai al-habs yang artinya diam, cegahan, rintangan, halangan, dan pengamanan. Penggunaan kata al-habs dengan arti wakaf terdapat dalam beberapa riwayat. Pertama, dalam hadis riwayat Imam Bukhori dari Ibnu Umar yang menjelaskan bahwa Umar bin Khattab datang kepada Nabi Saw. meminta petunjuk pemanfaatan tanah miliknya di Khaibar. Lalu Nabi Muhammad Saw. bersabda:

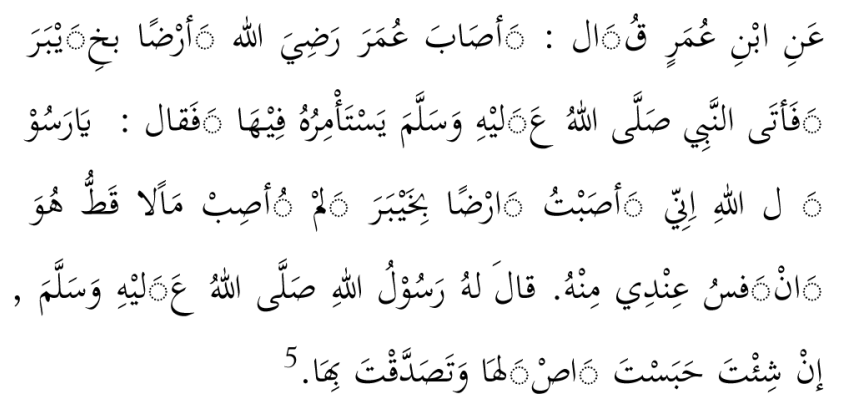

"Bila engkau menghendaki, tahanlah pokoknya dan sedekahkanlah hasilnya (manfaatnya).

Imam Bukhari selanjutnya mengutip penjelasan Ibnu Umar yang mengatakan:

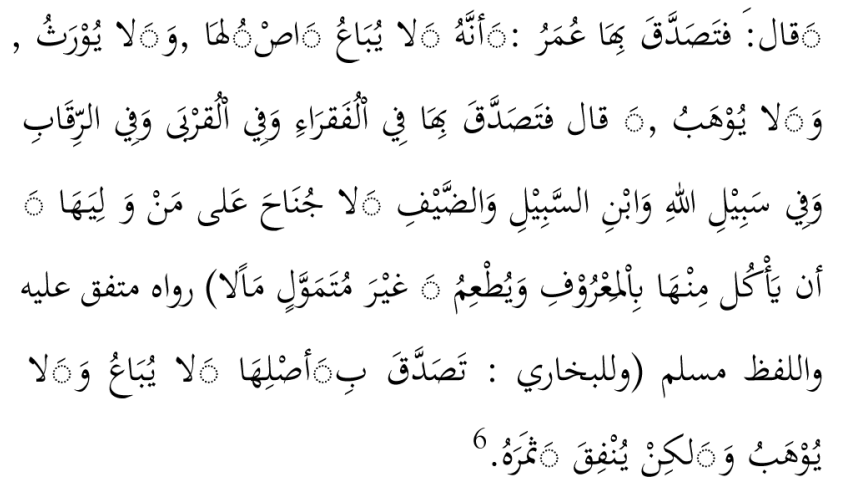

"Umar ra. menyedekahkan tanahnya di Khaibar, tanah itu tidak dijual, tidak dihibahkan, dan tidak pula diwariskan kepada orang-orang fakir, kerabat, hamba, kepentingan umum, tamu dan ibnu sabil. Orang yang memeliharanya (nazhir) dibolehkan memakan hasil tanah tersebut dengan cara yang ma'ruf (baik) serta tidak berlebihan”.

Kedua, dalam hadis riwayat Ibnu Abbas (yang dijadikan alasan hukum oleh Abu Hanifah) dijelaskan bahwa Nabi Muhammad Saw. bersabda:

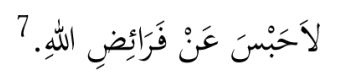

"Harta yang sudah berkedudukan sebagai tirkah (harta pusaka) tidak lagi termasuk benda wakaf".

\footnotetext{
${ }^{2}$ Taqiyudin Abi Bakar Ibnu Muhammad al-Husaini al-Dimasqi, Kifayatul Akhyar fii Hall Gayat al-Ikhtishar, (Semarang: Toha Putra, t.th), juz I, h. 319

${ }^{3}$ QS. Al-Baqarah (2): 180

${ }_{5}^{4}$ Imam Muslim, Shahih Muslim, (Beirut: Darul Kutub al-Alamiyah, 1991) juz III, No.1631, h.1255

${ }^{5}$ Ibid

${ }^{6}$ Imam Bukhari, Shahih Bukhari, (Semarang: Toha Putra, 1981), juz III, h.196

${ }^{7}$ Ali Fikri, Al-Muamamalah al-Madiyah wal Adabiyah (Mesir: Musthafa al-Babial-Halabi, 1938), juz II,h.300
} 
Ketiga, sebab nuzul (salah satu ayat) dalam surat an-nisa dalam penjelasan Imam Syuraih adalah bahwa:

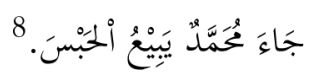

"Nabi Muhammad Saw. menjual benda wakaf."

Atas dasar sejumlah riwayat tersebut, nomenklatur wakaf dalam kitab-kitab hadis dan fikih tidaklah seragam. As-Syarkhasi dalam kitab al-Mabsuth memberikan nomenklatur wakaf dengan al-waqfu, sedangkan as-Syafi'i dalam kitab al-Umm memberikan 'nomenklatur wakaf dengan al-ahbas. ${ }^{9}$

Baik al-ahbas maupun al-waqf sama-sama mengandung makna al-imsak (menahan), alman'u (mencegah atau melarang), dan attamakkuts (diam). Disebut menahan karena wakaf ditahan dari kerusakan, penjualan dan semua tindakan yang tidak sesuai dengan tujuan wakaf. Dikatakan menahan, juga karena manfaat dan hasilnya ditahan dan dilarang bagi siapa pun selain dari orang-orang yang termasuk berhak atas wakaf tersebut. ${ }^{10}$

Pengelolaan harta wakaf yang terjadi dalam kehidupan masyarakat belum sepenuhnya berjalan tertib dan efisien sehingga dalam berbagai kasus harta benda wakaf tidak terpelihara sebagaimana mestinya, terlantar atau beralih ke tangan pihak ketiga dengan cara melawan hukum. Berbagai kasus bermunculan berkenaan dengan praktek pengelolaan harta wakaf yang bermuara pada timbulnya sengketa wakaf yang tidak mudah untuk diselesaikan. Keadaan demikian itu, tidak hanya karena masih banyaknya masyarakat yang kurang peduli atau belum memahami status harta benda wakaf yang seharusnya dilindungi demi kesejahteraan umum sesuai dengan tujuan, fungsi, dan peruntukan wakaf. Namun juga bisa disebabkan karena kelalaian atau ketidak mampuan nazhir dalam mengelola dan mengembangkan harta wakaf.

Sejatinya pengelolaan harta wakaf sangat bergantung pada nazhirnya. Sehingga produktif atau tidaknya harta wakaf sangat ditentukan oleh kemampuan dan pengetahuan nazhir. Dalam hal demikian, pada dasarnya peran nazhir sebagai pengelola wakaf tidak hanya sekedar menjaga dan melakukan hal-hal yang bersifat rutinitas, melainkan juga mencari inovasi-inovasi baru dalam rangka mengembangkan dan memberdayakan aset wakaf tersebut. Untuk itu, perlu ada upaya perbaikan yang bertujuan untuk membenahi manajemen wakaf dan menghilangkan sebabsebab keterpurukan manajemen wakaf akibat ulah nazhir dan kelalaiannya.

Nazhir wakaf telah diatur dalam UndangUndang No. 41 Tahun 2004 tentang wakaf dengan sangat rinci. Hal demikian menunjukkan bahwa nazhir memiliki kedudukan yang signifikan di dalam Undang-Undang tersebut. Di samping itu, ada kesan kuat, eksistensi wakaf dan pemberdayaannya sangat tergantung pada nazhir. Atau dengan kata lain, jika ada harta wakaf yang tidak produktif, atau harta wakaf yang hilang atau yang dialihkan, maka akar muaranya adalah pada nazhir yang kurang mampu menjalankan fungsinya dengan baik.

Peranan nazhir yang begitu besar dalam pengelolaan harta wakaf merupakan pembahasan yang menarik untuk diteliti secara mendalam, sebab sejatinya apa yang dilakukan nazhir dalam rangka memberdayakan harta wakaf haruslah sejalan dengan undang-undang dan hukum Islam. Dengan kata lain inovasi-inovasi yang dihasilkan oleh nazhir pun harus mengacu pada undangundang wakaf yang berlaku di Indonesia.

Dalam penelitian ini penulis meneliti aturanaturan tentang nazhir yang terdapat dalam Undang-Undang No. 41 Tahun 2004 serta implementasi yang dilakukan oleh organisasi

\footnotetext{
${ }^{8}$ Ibid

${ }^{9}$ Muhammad Ibn Idris as-Syafi'i, al-Umm (Mesir: Maktabah Kuliyah al-Azhariyah. t.th), juz III, h. 51

${ }^{10}$ Istiah al-habs digunakan di Afrika sedangkan istilah al-Waqf digunakan negara-negara muslim lainnya termasuk di Indonesia
} 
Islam yang notabene terbesar di Indonesia yaitu Nahdlatul Ulama dan Muhammadiyah. Adapun lingkup penelitian ini penulis batasi hanya pada kepengurusan NU dan Muhammadiyah Kota Bandung.

\section{B. Konsep Nazhir Wakaf dalam perspektif Undang-undang nomor 41 tahun 2004 tentang wakaf}

\section{Pengertian Nazhir}

Menurut undang-undang nomor 41 tahun 2004 pasal 1 ayat (4) tentang wakaf menjelaskan bahwa nazhir adalah pihak yang menerima harta benda wakaf dari wakif untuk dikelola dan dikembangkan sesuai dengan peruntukannya. Pengertian ini kemudian di Indonesia dikembangkan menjadi kelompok orang atau badan hukum yang diserahi tugas untuk memelihara dan mengurus benda wakaf.

Dari pengertian nazhir yang telah dikemukakan di atas, nampak bahwa dalam perwakafan, nazhir memegang peranan yang sangat penting. Agar harta itu dapat berfungsi sebagaimana mestinya dan dapat berlangsung terus-menerus, maka harta itu harus dijaga, dipelihara, jika mungkin dikembangkan. ${ }^{11}$

\section{Macam-Macam Nazhir dan ketentuannya}

Berdasarkan definisi nazhir yang telah diuraikan di muka, dapat dipahami bahwa yang dapat ditunjuk sebagai nazhir adalah harus berbentuk kelompok perorangan atau badan hukum. Ketentuan ini merupakan pembaharuan dari ketentuan yang ada dalam fiqh, yang menyebutkan bahwa nazhir dapat berupa perorangan secara sendiri asalkan ditunjuk oleh wakif, dan bahkan wakif sendiri dapat menunjuk dirinya sendiri menjadi nazhir. ${ }^{12} \mathrm{Hal}$ ini sebagaimana yang disebutkan dalam kitab Nihayah al-Muhtaj, bahwa jika wakif mensyaratkan nazhir kepada dirinya maka ikutilah atau jika mensyaratkan kepada orang lain juga penuhilah syarat itu. Tetapi jika wakif tidak mensyaratkan kepada seorang pun, maka yang bertindak sebagai nazhir adalah qadli. ${ }^{13}$ Qadli yang dimaksud di sini harus berasal dari negeri pihak yang berhak menerima hasil wakaf.

1) Nazhir Perorangan

Secara umum, ketentuan mengenai nazhir dalam peraturan pemerintah dapat dibedakan menjadi dua, ketentuan umum dan ketentuan khusus.

Ketentuan umum yang berkaitan dengan nazhir ialah:

a. Harta benda wakaf harus didaftarkan atas nama nazhir untuk kepentingan pendayagunaan wakaf sebagaimana yang tercatat dalam akta ikrar wakaf sesuai dengan peruntukannya.

b. Pendaftaran harta benda wakaf atas nama nazhir tidak membuktikan kepemilikan nazhir atas harta benda wakaf.

c. Penggantian nazhir tidak mengakibatkan peralihan harta benda wakaf yang bersangkutan.

Kewajiban dan sanksi bagi nazhir karena mengabaikan kewajibannya adalah bahwa nazhir yang tidak melaksanakan kewajibannya dalam jangka waktu 1 tahun sejak akta ikrar wakaf dibuat, kepala KUA atas inisiatif sendiri atau atas usul wakif atau ahli warisnya berhak mengusulkan kepada Badan Wakaf Indonesia untuk memberhentikan dan menggantikan nazhir.

2) Nazhir Organisasi

Ketentuan mengenai nazhir yang berbentuk organisasi ialah:

a. Nazhir organisasi wajib didaftarkan pada Menteri Agama dan Badan Wakaf Indonesia melalui KUA setempat.

\footnotetext{
${ }^{11}$ Lihat Panduan Wakaf, (Jakarta: Majelis Wakaf dan ZIS PP. Muhammadiyah, 2010), h.. 25-26

${ }^{12}$ Taufiq Hamami, Perwakafan Tanah dalam Politik Hukum Agraria Nasional, (Jakarta: Tatanusa, 2003), h. 99

${ }^{13}$ Ibnu Syihab al-Ramli,...., h. 613
} 
b. Nazhir organisasi yang melaksanakan pendaftaran harus memenuhi persyaratan.

c. Pendaftaran nazhir organisasi dilakukan sebelum penandatangan akta ikrar wakaf.

Sedangkan ketentuan-ketentuan mengenai pembubaran dan penggantian nazhir organisasi ialah:

a. Nazhir organisasi bubar atau dibubarkan sesuai dengan anggaran dasar organisasi yang bersangkutan.

b. Apabila salah seorang nazhir organisasi meninggal, mengundurkan diri atau dibatalkan kedudukannya sebagai nazhir, ia harus diganti.

c. Apabila nazhir perwakilan organisasi tidak melaksanakan tugasnya dan atau melakukan pelanggaran dalam pendayagunaan wakaf, pengurus pusat organisasi yang bersangkutan wajib mengatasi dan menyelesaikannya, baik diminta oleh BWI maupun tidak.

d. Nazhir organisasi yang tidak menjalankan kewajibannya, dapat diberhentikan dan diganti haknya ke nazhir yang lain oleh BWI dengan memperhatikan saran dan pertimbangan MUI setempat.

e. Nazhir organisasi yang tidak menjalankan kewajibannya dalam jangka waktu satu tahun (sejak akta ikrar wakaf dibuat), dapat diusulkan kepada BWI oleh kepala KUA untuk di berhentikan dan diganti oleh nazhir lain.

f. Apabila salah seorang nazhir organisasi meninggal, mengundurkan diri, berhalangan tetap dan atau dibatalkan kedudukannya sebagai nazhir yang di angkat oleh organisasi yang bersangkutan harus melapor ke KUA untuk selanjutnya diteruskan kepada BWI paling lambat 30 hari sejak kejadian tersebut.

\section{3) Nazhir Badan Hukum}

Ketentuan nazhir badan hukum pada umumnya sama dengan ketentuan nazhir organisasi. Bahwa nazhir badan hukum wajib didaftarkan pada menteri agama dan BWI melalui KUA setempat dan nazhir badan hukum yang melaksanakan pendaftaran harus memenuhi persyaratan-persyaratan yang telah ditentukan.

Sedangkan ketentuan-ketentuan mengenai pembubaran dan pergantian nazhir badan hukum ialah:

a. Apabila nazhir perwakilan daerah dari suatu badan hukum tidak menjalankan kewajibannya, pengurus pusat badan hukum yang bersangkutan wajib mengatasi dan menyelesaikannya baik diminta oleh BWI maupun tidak.

b. Apabila pengurus pusat badan hukum yang bersangkutan tidak dapat menjalankan kewajibannya, nazhir badan hukum tersebut dapat diberhentikan dan diganti hak kenazhirannya oleh BWI dengan memperhatikan saran dan pertimbangan MUI setempat.

c. Nazhir badan hukum yang tidak menjalankan kewajibannya dalam jangka waktu satu tahun (sejak akta ikrar wakaf dibuat), dapat diusulkan kepada BWI oleh kepala KUA untuk di berhentikan dan diganti oleh nazhir lain.

\section{Syarat-Syarat Nazhir}

Pada dasarnya, siapapun dapat menjadi nazhir sepanjang ia bisa melakukan tindakan hukum. Namun, Karena tugas nazhir menyangkut harta benda yang manfaatnya untuk kepentingan kesejahteraan masyarakat, tentunya jabatan nazhir diberikan pada pihak yang mampu menjalankan tugas tersebut.

Adapun nazhir yang perorangan menurut ketentuan pasal 219 Kompilasi hukum Islam harus memenuhi syarat-syarat sebagai berikut:

1) Beragama Islam. 
2) Warga Negara Indonesia.

3) Baligh (sudah dewasa).

4) Sehat jasmani dan rohani.

5) Tidak berada di bawah pengampunan.

6) Bertempat tinggal di kecamatan tempat letak benda yang diwakafkannya. ${ }^{14}$

Kemudian jika nazhir dalam bentuk badan hukum, maka harus memenuhi persyaratan sebagai berikut :

1) Badan hukum Indonesia dan berkedudukan di Indonesia.

2) Mempunyai perwakilan di kecamatan tempat letak benda yang diwakafkan.

Berdasarkan uraian di atas, baik nazhir perorangan maupun badan hukum, harus didaftarkan pada Kantor Urusan Agama Kecamatan setempat setelah mendengar saran dari Camat dan Majelis Ulama kecamatan untuk mendapat pengesahan. Sebelum melaksanakan tugas, nazhir harus mengucapkan sumpah di hadapan Kepala Kantor Urusan Agama Kecamatan disaksikan sekurang-kurangnya 2 orang saksi. Mengenai jumlah nazhir yang diperbolehkan untuk satu unut perwakafan yaitu terdiri atas 3 (tiga) orang dan sebanyak-banyaknya 10 (sepuluh) orang yang diangkat oleh kepala Kantor Urusan Agama Kecamatan atas saran Majlis Ulama Kecamatan dan camat setempat.

Dalam Bab I Pasal I poin 4 Undang - undang Republik Indonesia No. 41 tahun 2004 tentang wakaf, Nazhir adalah pihak yang menerima harta benda wakaf dari wakif untuk dikelola dan dikembangkan sesuai dengan peruntukannya.

Di dalam Undang-Undang No.41 Tahun 2004 tentang Wakaf, Bagian Kelima pasal 9, dijelaskan bahwa nazhir meliputi:

1) Perseorangan

2) Organisasi

3) Badan hukum.
Di dalam pasal 10 ayat 1 disebutkan, perseorangan yang dimaksud dalam pasal 9, hanya dapat menjadi nazhir apabila memenuhi persyaratan:

1) Warga negara Indonesia

2) Beragama Islam

3) Dewasa

4) Amanah

5) Mampu secara jasmani dan rohani

6) Tidak terhalang melakukan perbuatan hukum.

Di dalam ayat 2 disebutkan, organisasi sebagaimana dimaksud dalam pasal 9, hanya dapat menjadi nazhir apabila memenuhi persyaratan:

1) Pengurus organisasi yang bersangkutan memenuhi persyaratan nazhir perseorangan sebagaimana dimaksud pada ayat (1).

2) Organisasi yang bergerak di bidang sosial, pendidikan, kemasyarakatan dan/atau keagamaan Islam.

Ayat 3 menyebutkan, badan hukum sebagaimana dimaksud dalam pasal 9, hanya dapat menjadi nazhir apabila memenuhi persyaratan:

1) Pengurus badan hukum yang bersangkutan memenuhi persyaratan nazhir perseorangan sebagaimana dimaksud pada ayat (1).

2) Badan hukum Indonesia yang dibentuk sesuai dengan peraturan perundangundangan yang berlaku.

3) Badan hukum yang bersangkutan bergerak di bidang sosial, pendidikan, kemasyarakatan, dan/atau keagamaan Islam.

Dalam pasal 11 disebutkan, nazhir mempunyai tugas:

1) Melakukan pengadmistrasian harta benda wakaf;

2) Mengelola dan mengembangkan harta benda wakaf sesuai dengan tujuan, fungsi dan peruntukannya;

\footnotetext{
h. 143

${ }^{14}$ Abdul Gani Abdullah, Pengantar Kompilasi Hukum Islam dalam Tata Hukum Indonesia, Cet. 1, (Jakarta: Gema Insani Press, 1994),
} 
3) Mengawasi dan melindungi harta benda wakaf;

4) Melaporkan pelaksanaan tugas kepada Badan Wakaf Indonesia.

Pasal 12 menyebutkan, dalam melaksanakan tugas sebagaimana dimaksud dalam pasal 11, nazhir dapat menerima imbalan dari hasil bersih atas pengelolaan dan pengembangan harta benda wakaf yang besarnya tidak melebihi 10\% (sepuluh persen).

Pasal 13 menyebutkan, dalam melaksanakan tugas sebagaimana dimaksud dalam pasal 11, nazhir memperoleh pembinaan dari Menteri dan Badan Wakaf Indonesia. Dalam pasal 14 ayat 1 disebutkan, dalam rangka pembinaan sebagaimana dimaksud dalam pasal 13, nazhir harus terdaftar pada Menteri dan Badan Wakaf Indonesia. Dalam ayat 2 disebutkan, ketentuan lebih lanjut mengenai nazhir sebagaimana dimaksud dalam pasal 9, pasal 10, pasal 11, pasal 12, pasal 13 dan pasal 14 diatur dengan Peraturan Pemerintah. ${ }^{15}$

Berikut ini persyaratan umum lain bagi nazhir, yaitu:

1) Nazhir adalah pemimpin umum dalam wakaf.

Oleh karena itu nazhir harus berakhlak mulia, amanah, berpengalaman, menguasai ilmu administrasi dan keuangan yang dianggap perlu untuk melaksanakan tugas-tugasnya sesuai dengan jenis wakaf dan tujuannya.

2) Nazhir bisa bekerja selama masa kerjanya dalam batasan undang-undang wakaf sesuai dengan keputusan organisasi sosial dan dewan pengurus. Nazhir mengerjakan tugas harian yang menurutnya baik dan menentukan petugas-petugasnya, serta punya komitmen untuk menjaga keutuhan harta wakaf, meningkatkan pendapatannya, menyalurkan manfaatnya. Nazhir juga menjadi utusan atas nama wakaf terhadap pihak lain ataupun di depan mahkamah (pengadilan).

3) Nazhir harus tunduk kepada pengawasan Kementerian Agama dan Badan Wakaf Indonesia, dan memberikan laporan keuangan dan administrasi setiap seperempat tahun minimal, tentang wakaf dan kegiatannya.

4) Nazhir bertanggung jawab secara pribadi atas kerugian atau hutang yang timbul dan bertentangan dengan undang-undang wakaf. $^{16}$

\section{Hak, kewajiban, dan tangggung jawab Nazhir}

Di dalam Peraturan Pemerintah dan juga Peraturan Menteri Agama disebutkan beberapa pasal dan ayat mengenai hak dan kewajiban nazhir, di antaranya ${ }^{17}$ :

Adapun kewajiban nazhir adalah sebagai berikut:

1) Mengurus dan mengawasi harta wakaf, yaitu:

a. Menyimpan lembar kedua salinan akta ikrar

b. Memelihara tanah wakaf

c. Memanfaatkan tanah wakaf

d. Memelihara dan berusaha meningkatkan hasil wakaf

e. Menyelenggarakan pembukuan wakaf, yaitu:

1. Buku tentang keadaan tanah wakaf

2. Buku tentang pengelolaan dan hasil

3. Buku tentang penggunaan hasil (pasal 7 ayat $1 \mathrm{PP}$, pasal 10 ayat 1 PMA).

2) Memberikan laporan kepada KUA Kecamatan, yaitu:

a. Hasil pencatatan wakaf tanah milik oleh pejabat agrarian

\footnotetext{
15 Undang-undang Nomor 41 Tahun 2004 tentang Wakaf, Peraturan Pemerintah Nomor 42 Tahun 2006 tentang Pelaksanaannya, Peraturan Menteri Agama Nomor 4 Tahun 2009 tentang Administrasi Pendaftaran Wakaf Uang, (Jakarta: Dirjen Bimas Islam Depag RI, 2009), h.7-9

${ }^{16}$ Mundzir Qahaf, Manajemen Wakaf Produktif. (Jakarta: Khalifa, 2008), h. 171-172

${ }^{17} \mathrm{http}: / /$ bwi.or.id/index.php/artikel/740-standarisasi-dan-profesionalisme-nazhir-di-indonesia
} 
b. Perubahan status tanah dan perubahan penggunaannya.

c. Pelaksanaan kewajiban nazhir pasal 20 ayat 1 PP setiap tahun sekali pada akhir bulan Desember.

3) Melaporkan anggota nazhir yang berhenti dari jabatan

4) Mengusulkan anggota pengganti kepada Kepala KUA Kecamatan tempat tanah wakaf berada, untuk disahkan keanggotaannya. ${ }^{18}$

Semua ini dilakukan untuk memudahan koordinasi dan pengawasan, dan oleh sebab itu nazhir berhak mendapatkan penghasilan dan fasilitas yang wajar atas usaha dan jerih payahnya (pasal 8 PP) untuk menghindari penyalahgunaan tujuan wakaf.

Sedangkan hak-hak seorang nazhir adalah sebagai berikut :

1) Menerima penghasilan dari hasil-hasil tanah wakaf yang besarnya telah ditentukan oleh Kepala Kandepag, Kepala seksi urusan Agama Islam dengan ketentuan tidak melebihi dari $10 \%$ dari hasil bersih tanah wakaf. ${ }^{19}$

2) Berhak menggunakan fasilitas benda wakaf dalam menjalankan tugasnya sebagai nazir, yang jenis dan jumlah fasilitasnya ditentukan oleh Kepala Kandepag, cq. Kasi Urais. ${ }^{20}$

Menurut Zainuddin, ${ }^{21}$ seorang Nazhir boleh menerima upah yang disyaratkan oleh pewakaf, sekalipun jumlahnya lebih besar daripada upah yang sepantasnya, selain dia bukan pewakaf sendiri.

Sedangkan tanggung jawab Nazhir adalah sebagai berikut:

1) Dalam hal ini ada beberapa kondisi dimana nazhir tidak wajib memberikan ganti rugi dan kondisi dimana nazhir wajib memberikan ganti rugi. Nazhir tidak wajib memberikan ganti rugi jika harta wakaf rusak karena kekuasaan yang besar yang sulit ditolak atau bencana yang tidak bisa dicegah. Dan jika harta wakaf tersebut hilang atau rusak dan bukan disebabkan kelalaian atau keteledoran maka tidak wajib mengganti harta atau barang wakaf tersebut.

2) Nazhir wajib mengganti rugi karena Pertama, kelalaian dan keteledoran nazhir dalam menjaga harta wakaf. Kedua, nazhir menggunakan harta wakaf yang berada dalam kekuasaannya untuk kepentingan pribadi atau urusan keluarganya. Ketiga, jika para mustahik meminta bagian kepada nazhir lalu dia menolak tanpa alasan yang benar dan sesuai syariat. Empat, jika nazhir menyewakan bangunan wakaf dengan harga yang lebih kecil dari harga yang semestinya. Lima, jika nazhir meninggal dan tanpa mengetahui jumlah harta wakaf yang dikelolanya

\section{Kewenangan Nazhir}

a. Hal yang boleh dilakukan oleh Nazhir

1) Menyewakan harta wakaf

Nazhir berwenang untuk menyewakan harta wakaf jika menurutnya akan mendatangkan keuntungan dan tidak ada pihak yang melarangnya. Keuntungan tersebut dapat digunakan nazhir untuk membiayai hal-hal yang telah ditentukan oleh waqif.

2) Menanami tanah wakaf

Nazhir boleh memanfaatkan tanah wakaf dengan menanami dengan aneka jenis tanaman perkebunan. Dengan memperhatikan dampak pada tanah wakaf dan kepentingan para mustahik.

\footnotetext{
${ }^{18}$ Farid Wadjdy dan Mursyid.....,h.169

${ }^{19}$ Suparman Usman. Hukum Perwakafan di Indonesia. (Menara Kudus: Darul Ulum Press, 1994), h. 81

${ }^{20}$ Juhaya S. Praja, op. cit., hlm. 45

${ }^{21}$ Zainuddin bin Abdul Aziz, Fathul Muin Bisyarh Qurratu 'Ain, (Semarang: Toha Putra, 2000), h. 91
} 
3) Membangun pemukiman di atas tanah wakaf untuk disewakan

Nazhir berwenang mengubah tanah wakaf yang letaknya berdekatan dengan kota menjadi bangunan untuk disewakan dengan dua syarat yaitu: Pertama, Adanya kemauan dan kebutuhan masyarakat untuk menyewa gedung tersebut. Kedua, Keuntungan yang didapat dari hasil sewa bangunan lebih besar ketimbang jika digunakan untuk lahan pertanian.

4) Mengubah kondisi tanah wakaf

Nazhir berwenang untuk mengubah keadaan dan bentuk harta wakaf menjadi lebih baik dan bermanfaat bagi para fakir miskin dan mustahik. Sedangkan menurut Zainuddin, bahwa Nazhir wakaf boleh membelanjakan hasil wakaf, dan hakim boleh memakan sebagian dari hasilnya. ${ }^{22}$

b. Hal yang tidak boleh dilakukan oleh Nazhir

1) Tidak boleh melakukan dominasi atas harta wakaf

2) Tidak boleh berhutang atas nama wakaf

3) Tidak boleh menggadaikan tanah wakaf

4) Tidak boleh mengizinkan seseorang menggunakan harta wakaf tanpa bayaran, kecuali dengan alasan hukum

5) Tidak boleh meminjamkan harta wakaf

\section{Tugas dan Sanksi Nazhir}

Tugas-tugas nazhir antara lain mengurus dan mengawasi harta kekayaan wakaf dan hasilnya, yaitu meliputi Pengelolaan dan Pemeliharaan harta wakaf serta meningkatkan hasil wakaf, membuat laporan secara berkala atas semua yang menjadi tanggung jawabnya. Dalam menjalankan tugasnya nazhir berhak mendapatkan penghasilan dan fasilitas yang jumlanya ditentukan berdasarkan kelayakan atas saran Majelis Ulama Kecamatan dan Kantor Urusan Agama Kecamatan setempat.

Secara rinci dalam pasal 11 Undang-Undang Nomor 41 Tahun 2004 disebutkan tugas nazhir tersebut, yaitu:

a. Melakukan pengadministrasian hata benda wakaf;

b. Mengelola dan mengembangkan harta benda wakaf sesui dengan tujuan, fungsi daan peruntukannnya

c. Mengawasi dan melindungi harta benda wakaf

d. Melaporkan pelaksanaan tugas kepada Badan Wakaf Indonesia.

Adapun sanksi bagi nazhir karena mengabaikan kewajibannya adalah bahwa nazhir yang tidak melaksanakan kewajibannya dalam jangka waktu 1 tahun sejak akta ikrar wakaf dibuat, kepala KUA atas inisiatif sendiri atau atas usulan wakif atau ahli warisnya berhak mengusulkan kepada Badan Wakaf Indonesia untuk memberhentikan dan menggantikan nazhir.

\section{Pengangkatan dan Pemberhentian Nazhir}

Pada hakekatnya siapa saja bisa menjadi nazhir, asalkan orang itu memenuhi kriteria atau syarat-syarat untuk menjadi nazhir. Tetapi yang menjadi persoalan adalah siapa yang berhak menunjuk atau mengangkat nazhir. Menurut fiqh, seorang wakif bisa menunjuk dirinyasendiri atau orang lain untuk menjadi nazhir, tetapi jika wakif tidak menunjuk siapapun untuk menjadi nazhir, maka yang bertindak sebagai nazhir adalah qadli dari pihak desa tempat wakaf tersebut. $^{23}$

\footnotetext{
${ }^{22}$ Zainuddin bin Abdul Aziz, Fathul Mu'in Bisyarh Qurrati Al-Ain,....h. 89

${ }^{23}$ Ibnu Syihab al-Ramli,.........., h. 397
} 
Sedangkan dalam peraturan perundangan tidak ada suatu ketentuan yang menyebutkan siapa yang berhak mengangkat nazhir (pengelola wakaf). Namun jika dilihat dari beberapa ketentuan yang diatur dalam PP. No. 28 Tahun 1977, secara tersirat dapat dipahami bahwa yang berhak menunjuk dan mengangkat nazhir adalah adalah pihak wakif dengan mengajukan ke pihak Kantor Urusan Agama Kecamatan setempat, untuk didaftar dan disahkan dengan melihat persyaratan yang ada. ${ }^{24}$

Namun jika di suatu desa telah ada nazhir yang telah didaftar dan disahkan oleh Kepala Kantor Urusan Agama (KUA) Kecamatan, maka untuk wakif-wakif selanjutnya, tidak boleh menunjuk dan mengangkat nazhir yang baru di desa tersebut. Dengan demikian kebebasan wakif untuk menunjuk dan mengangkat nazhir sebagaimana menurut fiqh tidak bisa dipenuhi, karena demi tertibnya lembaga perwakafan di Indonesia. Di sinilah nampak bahwa peraturan perwakafan yang dikeluarkan pemerintah lebih menekankan pada aspek prosedural dan formalitas.

Dalam Kompilasi Hukum Islam tidak ditentukan masa jabatan nazhir, tetapi dalam keadaan tertentu nazhir dapat diberhentikan oleh Kepala Kantor Urusan Agama Kecamatan yang bersangktan. Ketentuan Pasal 221 Kompilasi Hukum Islam menentukan:

1) Nazhir diberhentikan oleh Kepala Kantor Urusan Agama Kecamatan karena:
a. Meninggal dunia.
b. Atas permohonan sendiri.
c. Tidak melakukan kewajibannya lagi sebagai nazhir.
d. Melakukan suatu kejahatan sehingga dipidana.

2) Bilamana terdapat lowongan jabatan nazhir, karena salah satu alasan di atas, maka penggantinya diangkat oleh Kepala Kantor
Urusan Agama Kecamatan atas saran Majelis Ulama Kecamatan dan camat setempat.

Seorang nazhir yang telah berhenti tidak dengan sendirinya diganti oleh salah seorang ahli warisnya..$^{25}$

Sementara itu, Rachmadi² Usman menambahkan bahwa karena sesuatu halnya nazhir dapat diberhentikan dan diganti dengan nazhir lain apabila yang bersangkutan:

a. Meninggal dunia bagi nazhir perseorangan;

b. Bubar atau dibubarkan sesuai dengan ketentuan peraturan perundang-undangan yang berlaku untuk nazhir organisasi atau nazhir badan hukum;

c. Atas permintaan sendiri

d. Tidak melaksanakan tugasnya sebagai nazhir dan atau melanggar ketentuan larangan dalam pengelolaan dan pengembangan harta benda wakaf sesuai dengan ketentuan peraturan perundang-undangan yang berlaku;

e. Dijatuhi hukuman pidana oleh pengadilan yang telah mempunyai kekuatan hukum tetap.

Pemberhentian dan penggantian nazhir karena alasan sebagaimana tersebut di atas dilaksanakan oleh Badan Wakaf Indonesia, dengan ketentuan bahwa pengelolaan dan pengembangan harta benda wakaf yang dilakukan oleh nazhir lain karena pemberhentian dan penggantian nazhir, dilakukan dengan tetap memperhatikan peruntukan harta benda wakaf yang ditetapkan dan tujuan serta fungsi wakaf. ${ }^{27}$

\section{Nazhir dan Pengawasan Harta Wakaf}

Untuk menjaga agar harta wakaf mendapat pengawasanan jangka dengan baik, kepada nazhir dapat diberikan imbalan yang ditetapkan dengan jangka waktu tertentu atau mengambil sebagian dari hasil harta wakaf yang dikelolanya. Untuk menjamin agar perwakafan dapat terselenggara

\footnotetext{
24 Taufiq Hamami,.........., h. 103

25 Abdul Gani Abdullah, Pengantar Kompilasi Hukum Islam dalam Tata Hukum Indonesia, (Bandung: Fokusmedia, 1995), h. 144

${ }^{26}$ Lihat Rachmadi Usman, h.139

27 Rachmadi Usman, Hukum Perwakafan di Indonesia, (Jakarata: Sindar Grafika), h. 138-139
} 
dengan sebaik-baiknya, negara juga berhak atas pengawasan harta wakaf dengan mengkuarkan undang-undang yang mengatur persoalan wakaf, termasuk penggunaannya. ${ }^{28}$

Untuk memudahkan pengawasan diperlukan adanya administrasi yang tertib baik di tingkat kecamatan, kabupaten, propinsi dan pusat. Pengawasan dan bimbingan perwakafan tanah dilakukan oleh unit-unit organisasi Departemen Agama, ${ }^{29}$ secara hirarkis sebagaimana diatur dalam Keputusan Menteri Agama tentang Susunan Organisasi dan Tata Kerja Departemen Agama, yang tertuang pada Peraturan Menteri Agama Nomor 1 Tahun 1978 pasal 14. Untuk itu, agar pengawasan harta benda wakaf ini lebih bisa dipertanggungjawabkan, maka nazhir sebagai sebuah lembaga publik harus memiliki :

a. Sistem akuntansi dan manajemen keuangan.

Nazhir sebagai lembaga masyarakat dan ditugasi untuk mengelola benda wakaf, terutama benda wakaf produktif perlu memiliki menejemen dan akuntansi yang sistematis. Sistem tersebut dimaksudkan agar pengawasan kegiatan dan keuangan dapat dilakukan secara efektif dan akurat.

b. Sistem audit yang transparan. Nazhir dapat di audit secara internal oleh Kementerian Agama maupun eksternal oleh akuntan publik atau lembaga audit yang independen. Sasaran audit meliputi aspek kegiatan, keuangan, kinerja, peraturan-peraturan, tata kerja dan prisip-prinsip ajaran Islam.

Selain pengawasan yang bersifat umum berupa payung hukum yang memberikan ancaman terhadap pihak yang melakukan penyelewengan dan atau sengketa berkaitan dengan pengelolaan harta wakaf, upaya pengawasan benda wakaf dapat langsung dilakukan oleh pihak pemerintah dan masyarakat. Sebagaimana terlampir dalam pasal 21 bagian ketiga RUU Wakaf.

Peran pemerintah yang memiliki akses birokrasi yang sangat luas dan otoritas dalam melindungi eksistensi dan pengembangan wakaf secara umum. Demikian juga masyarakat sebagai pihak yang berkepentingan langsung terhadap pemanfaatan benda wakaf dapat mengawasi secara langsung terhadap jalannya pengelolaan wakaf. Tentu saja, pola pengawasan yang bisa dilakukan oleh masyarakat bukan bersifat interventif (campur tangan menejemen), namun memantau, baik langsung maupun tidak langsung terhadap pola pengelolaan dan pemanfaatan wakaf itu sendiri. Sehingga peran lembaga nazhir lebih terbuka dalam memberikan laporan terhadap kondisi dan perkembangan harta wakaf yang ada.

Dalam rangka memajukan dan mengembangkan perwakafan nasional dibentuk Badan Perwakafan Indonesia. Lembaga ini adalah lembaga independen yang mempunyai tugas dan wewenang sebagai berikut :

a. Melakukan pembinaan terhadap nazhir dalam mengelola dan mengembangkan harta benda wakaf,

b. Melakukan pengelolaan, pengembangan dan pengawasan harta benda wakaf berskala nasional,

c. Memberhentikan dan mengganti nazhir, dan lainnya.

Harta benda yang diwakafkan tersebut harus didaftarkan atas nama nazhir untuk kepentingan pihak yang dimaksud dalam Akta Ikrar Wakaf sesuai dengan peruntukannya. Terdaftarnya harta benda wakaf atas nama nazhir tidak membuktikan kepemilikan nazhir atas harta benda wakaf, hanya dimaksudkan sebagai bukti bahwa nazhir hanyalah pihak yang mengadministrasikan, mengelola, mengembangkan, mengawasi, dan melindungi harta benda wakaf. Penggantian nazhir tidak mengakibatkan peralihan harta benda wakaf yang bersangkutan.

Selama dan dalam melaksanakan tugasnya sebagai nazhir, nazhir berhak menerima penghasilan sebagai imbalan yang besarnya tidak

\footnotetext{
${ }^{28}$ Abdul Ghafur. Hukum dan Praktik Perwakafan. (Yogyakarta: Pilar Media. 2005)
} 
melebihi $10 \%$ (sepuluh persen) dari hasil bersih ataas pengelolaan dan pengembangan harta benda wakaf yang bersangkutan yang ditetapkan oleh Kepala Kantor Departemen Agama Kabupaten/ Kota yang bersangkutan serta fasilitas lainnya yang diperlukan dalam rangka mengadministrasi-kan, mengelola, mengembangkan, mengawasi, dan melindungi harta benda wakaf yang bersangkutan.

Dalam melaksanakan tugas sebagai nazhir, seorang nazhir berhak memperoleh pembinaan dari menteri yang bertanggung jawab di bidang agama dan badan wakaf indonesia dengan memperhatikan saran dan pertimbangan Majelis Ulama Indonesia sesuai dengan tingkatannya. Untuk keperluan itu dipersyaratkan, bahwa nazhir harus terdapat pada menteri yang bertanggung jawab di bidang agama dan badan wakaf indonesia. Pembinaan sebagaimana dimaksud meliputi:

a. Penyiapan sarana dan prasarana penunjang operasional nazhir wakaf biak perseorangan, organisasi, dan badan hukum;

b. Penyusunan regulasi, pemberian motivasi, pemberian fasilitas, pengkoordinasian, pemberdayaan, dan pengembangan terhadap harta benda wakaf;

c. Penyediaan fasilitas proses sertifikasi wakaf;

d. Penyiapan dan pengadaan blangko-blangko akta Ikrar Wakaf, baik wakaf benda tidak bergerak dan atau benda bergerak;

e. Penyiapan penyuluh penerangan di daerah untuk melakukan pembinaan dan pengembangan wakaf kepada nazhir sesuai dengan lingkupnya;

f. Pemberian fasilitas masuknya dana-dana wakaf dari dalam dan luar negeri dalam pengembangan dan pemberdayaan wakaf.

Pembinaan terhadap nazir dimaksud wajib dilakukan sekurang-kurangnya sekali dalam setahun dengan tujuan untuk peningkatan etika dan moralitas dalam pengelolaan wakafa serta untuk meningkatkan profesionalitas pengelolaan dana wakaf. Kerja sama dengan pihak ketiga, dalam rangka pembinaan terhadap kegiatan perwakafan di indonesia dapat dilakukan dalam bentuk penelitian, pelatihan, seminar, maupun kegiatan lainnnya.

Sementara itu, pengawasan terhadap perwakafan dilakukan pemerintah dan masyarakat, baik aktif maupun pasif. Pengawasan aktif dilakukan dengan melakukan pemeriksaan langsung terhadap nazhir atas pengelolaan wakaf, sekurang-kurangnya sekali dalam setahun. Pengawasan pasif dilakukan dengan melaukan pengamatan atas berbagai laporan yang disampaikan nazhir berkaitan dengan pengelolaan wakaf. Pemerintah dan masyarakat dalam melaksanakan pengawasan pengelolaan darta benda wakaf dapat meminta bantuan jasa akuntan publik independen.

Masa bakti nazhir adalah 5 (lima) tahun dan dapat diangkat kembali oleh Badan Wakaf Indonesia bila yang bersangkutan telah elaksanakan tugasnya dengan baik dalam periode sebelumnya sesuai ketentuan pronsip syariah dan peraturan perundang-undngan.

\section{Implementasi Nazhir Wakaf dalam Ormas Islam}

\section{Nahdhatul Ulama}

\section{a. Gambaran Umum LWPNU}

Lembaga Wakaf dan Pertanahan Nahdlatul Ulama merupakan lembaga yang lahir di NU sejak masa K.H. Hasyim Asy'ari. Sebuah dokumen autentik berupa STATUTEN dan REGLEMENT STIEHTING WAQFIAH telah dibuat pada tanggal 23 Februari 1937 di hadapan Notaris Hendrik Wiliem Nazembreg, Surabaya, yang terdiri atas 11 pasal atau artikel. Salah satu pasalnya menyebutkan bahwa Perhimpunan Nahdlatul Ulama secara resmi mendirikan Dewan Pengurus Wakaf, sebagai Rois adalah K.H. Hasyim Asy'ari, dan sebagai Khatib adalah KH. Wahab Hasbullah. ${ }^{30}$

\footnotetext{
${ }^{29}$ Suparman Usman, Ibid. 79

30 https://lwpnu.or.id/
} 
Keberadaan Stiehting Waifish Nahdlatul Ulama tersebut, telah dilengkapi dengan anggaran rumah tangga yang terdiri atas 31 pasal, yang salah satu pasalnya menyebutkan bahwa "harta wakaf boleh diambil buah atau hasilnya untuk kepentingan umum."

Anggaran Rumah Tangga Stiehting Waqfiah Nahdlatul Ulama tersebut disetujui secara resmi dalam Konggres Perhimpunan Nahdlatul Ulama ke 14, tanggal 4-5 Juli 1939, di Magelang dan dijadikan Plant Nahdlatul Ulama secara Nasional.

Struktur Stiehting Waqfiah Nahdlatul Ulama dari Mu'tamar ke Mu'tamar yang lain mengalami reposisi struktur, namun nama tetap menggunakan Stiehting Waqfiah. Pada Mu'tamar Nahdlatul Ulama ke 15, tanggal 10-15 Desember 1940, posisi Stiehting Waqfiah berada di bawah bagian harta yang langsung dalam pembinaan dan pengawasan Syuriyah.

Perkembangan selanjutnya nama Stiehting Waqfiah menjadi sub unit tersendiri yang berkedudukan di Surabaya dan cukup banyak harta yang masih dihimpun atas nama Stiehting Waqfiah baik yang berada di tingkat pusat di Surabaya maupun ditempat lainnya. Salah satunya yang tetap dipelihara dengan baik dan tetap dalam "Pengawasan Nahdlatul Ulama" sampai dengan sekarang yaitu tanah dan gedung Stiehting Waqfiah Nahdlatul Ulama di Bangil Kabupaten Pasuruan, dan sampai sekarang nama gedung itu bernama "Gedung Waqfiah".

Mu'tamar Nahdlatul Ulama ke 28, tanggal 2528 November 1989 di Yogyakarta, posisi struktur Stiehting Waqfiah, masuk perangkat berbentuk Lajnah dan namanya berubah menjadi Lajnah Waqfiah yang tugas pokoknya tetap sebagaimana tugas Stiehting. Nama dan posisi sebagai Lajnah Waqfiah pada saat Mu'tamar Nahdlatul Ulama ke 29, tanggal 1-5 Desember 1994 di Cipasung dimasukan dalam pasal 16 ayat 2 (e) Anggaran Rumah Tangga, yang bertugas untuk mengurus tanah dan bangunan yang diwakafkan kepada Nahdlatul Ulama.

Ketika Mu'tamar ke 30, tanggal 21-26 November 1999 di Lirboyo Kediri, nama Lajnah berubah menjadi AUQOF, jamak dari waqfiah, namun tugas dan wewenangnya tidak berubah. Dalam Mu'tamar di Kediri terdapat keputusan rekomendasi yang di tujukan kepada PBNU agar Stiehting Waqfiah yang kini di tangan perorangan Nahdlatul Ulama agar di bubarkan secara formal, sehingga tidak ada dualisme struktur.

Selanjutnya ketika Mu'tamar ke 31 pada tanggal 28 November-2 Desember 2004 di Boyolali Jawa Tengah, Lajnah Auqof diubah menjadi Lembaga Wakaf dan Pertanahan Nahdlatul Ulama disingkat LWP-NU yang bertugas mengurus, mengelolah serta mengembangkan tanah dan bangunan serta harta benda wakaf lainnya milik Nahdlatul Ulama.

Tugas inilah yang saat ini dikembangkan oleh LWP-NU sehingga diharapkan keberadaan lembaga ini dapat memberikan kontribusi dalam berupaya untuk mensejahterakan umat berdasarkan nilai-nilai agama yang menganut aswaja. $^{31}$

\section{b. Tugas dan Tujuan LWPNU}

Dalam pengurusan wakaf di NU terdapat lembaga khusus yang menanganinya yaitu Lembaga Wakaf dan Pertanahan (LWPNU) begitupun dengan NU kota Bandung. Secara umum lembaga ini secara intens bertugas menginventarisir aset wakaf yang dimiliki NU kota Bandung serta mengembangkannya untuk kemaslahatan umat. ${ }^{32}$

Sedangkan secara spesisifik lembaga ini mempunyai tugas yaitu:

a. Melakukan koordinasi dengan Pengurus LWPNU yang berkaitan dengan data asset baik sudah bersertifikat maupun yang masih dalam proses.

\footnotetext{
${ }^{31}$ Wawancara dengan KH. Wahyu Afif (Pengurus Cabang NU Kota Bandung) pada hari senin tanggal 9 April 2018

32 Wawancara dengan KH. Wahyu Afif (Pengurus Cabang NU Kota Bandung) pada hari senin tanggal 14 April 2018
} 
b. Mensertifikatkan tanah-tanah wakaf/ Hak milik PCNU yang belum sertifikat.

c. Menginput data asset NU yang telah bersertifikat ke dalam data base dan ke Web SIWAK NU.

d. Melakukan upaya-upaya pemberdayaan umat melalui gerakan wakaf dengan melalui aksi nyata.

e. Membina dan Memberdayakan Nazhir serta menjalin kerja sama dengan bank-bank syariah, OJK, BWI dan Lembaga-lembaga terkait.

Target dan tujuan lembaga ini adalah sebagai berikut yaitu:

a. Meningkatkan peran organisasi dalam pengembangan dan penataan pertanahan bebas dari sengketa.

b. Data administrasi asset; jumlah, luas dan lokasi wakaf maupun hal milik NU dapat dengan mudah dilihat maupun dibaca di data base maupun Web.

c. Menumbuhkan kecintaan, solidaritas dan kebersamaan kepada sesama umat dalam upaya meningkatkan wakaf untuk kesejahteraan umat.

d. Menggerakkan wakaf uang kepada seluruh Pengurus PCNU dan kepada seluruh Nahdliyin serta masyarakat pada umumnya. ${ }^{33}$

\section{c. Kondisi Perwakafan NU Kota Bandung}

Wakaf merupakan perbuatan hukum yang suci dan mulia, artinya selama barang yang diwakafkan dapat dimanfaatkan, pahalanya akan tetap mengalir, meskipun si wakif telah meninggal dunia. Wakaf secara signifikan menyumbangkan pertumbuhan budaya dan intelektual, dan berperan positif dalam menegakkan keadilan sosial, serta mendorong mereka yang kaya untuk mendirikan wakaf.

Dalam catatan sejarah NU, wakaf secara umum mampu menyejahterakan umat walaupun masih belum maksimal dalam mencapai spirit yang disyariatkan wakaf, padahal potensi wakaf di NU luar biasa. Hal ini karena banyak faktor yang terdistorsi, di antaranya pemahaman masyarakat akan wakaf, manajeman wakaf, harta yang diwakafkan dan nazhir.

Hal pokok yang sering menimbulkan permasalahan perwakafan dalam praktik di lapangan adalah masih banyaknya wakaf tanah yang tidak ditindaklanjuti dengan pembuatan akta ikrar wakaf. Pelaksanaan wakaf yang terjadi masih banyak yang dilakukan secara agamis atau mendasarkan pada rasa saling percaya. Kondisi ini, pada akhirnya menjadikan tanah yang diwakafkan tidak memiliki dasar hukum, sehingga apabila dikemudian hari terjadi permasalahan mengenai kepemilikan tanah wakaf penyelesaiannya akan menemui kesulitan, khususnya dalam hal pembuktian.

Selain hal di atas, yang sering menimbulkan permasalahan dalam praktik wakaf di Indonesia adalah dimintanya kembali tanah wakaf oleh ahli waris wakif dan tanah wakaf dikuasai secara turun temurun oleh Nazhir yang penggunaannya menyimpang dari akad wakaf. Dalam praktik sering didengar dan dilihat adanya tanah wakaf yang diminta kembali oleh ahli waris wakif setelah wakif tersebut meninggal dunia.

Salah satu penghambat pemberdayaan wakaf di NU Kota Bandung adalah pertama masalah pemahaman masyarakat tentang hukum wakaf; kedua pengelolaan dan manajemen wakaf setengah hati; ketiga benda yang diwakafkan dan nazhir. Kenyataan adanya berbagai problem terkait dengan sengketa dan pengelolaan tanah wakaf yang terjadi di tengah masyarakat harus di urus dan diselesaikan secara bijak dan benar. Agar supaya tujuan dari adanya wakaf itu sendiri dapat terjaga kesuciannya dan dapat digunakan sebagaimana mestinya. ${ }^{34}$

Beberapa solusi untuk meletakkan fondasi pengelolaan tanah wakaf dari berbagai hal yang

\footnotetext{
${ }^{33}$ https://1wpnu.or.id/tata-kerja

${ }^{34}$ Wawancara dengan KH. Wahyu Afif (Pengurus Cabang NU Kota Bandung) pada hari senin tanggal 29 April 2018
} 
tidak diinginkan adalah pertama, melakukan pemberdayaan wakaf secara produktif. Kedua, Badan Wakaf Indonesia melaksanakan pembinaaan dan pemberdayaan kepada para pengelola wakaf secara intens. Ketiga, melakukan penegakan hukum dalam pengelolaan wakaf secara prioritas. Keempat, melakukan pengawasan dan pendataan terhadap harta wakaf. Kelima, adanya i'tikad baik untuk memberi atau mengurus tanah wakaf. Keenam, memaksimalkan peran dan fungsi KUA sebagai wakil pemerintah di daerah dalam pembinaan dan penyuluhan di bidang perwakafan.

Memahamkan akan pentingya pengelolaan tanah wakaf secara profesional adalah sebuah cita-cita mulia, karena tanah wakaf merupakan aset untuk pemberdayakan dan pengembangan ummat dalam berbagai bidang, dan untuk itu tanah wakaf harus dimanfaatkan secara optimal, agar terwujud masyarakat yang sejahtera dan berkeadilan.

Pada dasarnya banyak sekali aset wakaf yang dimiliki oleh NU kota Bandung, namun dalam praktek di lapangan, tidak semua aset NU kota Bandung terinventarisir dengan nama NU kota Bandung. Namun banyak aset wakaf yang dimiliki oleh berbagai lembaga maupun yayasan berupa pondok pesantren. Sebagai nazhirnya adalah kyaikyai yang notabene sebagai pengasuh pesantren tersebut.

Dalam penentuan nazhir wakaf, NU Kota Bandung lebih mengedepankan seorang tokoh yang dipandang alim serta memiliki pengetahuan mumpuni khususnya berkenaan dengan fiqih wakaf dan mampu mengembangkan aset wakaf menjadi produktif.

Aset-aset wakaf yang dimiliki oleh NU kota Bandung tersebar dalam bentuk yaitu: (1) Pondok pesantren, (2) Lembaga pendidikan, (3), Masjid, (4) Panti asuhan.

Adapun pengelolaan aset-aset wakaf tersebut, sebagian besar dilakukan oleh nazhir yang merangkap sebagai dewan pengasuh lembaga tersebut. PCNU Kota Bandung hanya bertindak sebagai kordinator yang berfungsi memberikan arahan agar aset-aset wakaf tersebut bisa berkembang sebagaimana mestinya yang bermuara pada kemaslahatan umat.

Produktifitas tanah wakaf, secara umum sudah menampakan indikasi baik namun walaupun demikian belum seluruhnya bisa diproduktifkan sebagai lahan bisnis yang bisa mendatangkan keuntungan lebih besar. Hal demikian karena sebagian besar aset wakaf yang dikelola oleh NU kota Bandung berbentuk lembaga-lembaga keagamaan dan sosial yang jauh dari orientasi bisnis.

Selain itu, para pengasuh pondok pesantren yang berkedudukan sebagai nazhir yang mempunyai tanggung jawab mengembangkan aset wakaf yang dimiliki masih mengedepankan "keikhlasan" sepenuhnya. Artinya hak-hak mereka sebagai nazhir seringkali belum tercukupi secara nyata dari hasil pengembangan aset wakaf tersebut. $^{35}$

\section{Muhammadiyah}

\section{a. Gambaran Umum Majelis Wakaf dan Kehartabendaan}

Dalam hubungannya dengan pemikiran "mengkorporasikan" pengelolaan harta benda wakaf, maka Muhammadiyah sebagai organisasi keagamaan yang telah memperoleh status badan hukum (rechtpersoon) sejak masa pemerintahan kolonial Belanda (1914), telah menjalankan fungsinya sebagai nazhir. Status organisasi (keagamaan) sebagai nazhir telah diakui UndangUndang Nomor 41 Tahun 2004 tentang Wakaf, yaitu dengan memberikan kemungkinan suatu organisasi keagamaan bertindak sebagai nazhir harta benda wakaf.

Muhammadiyah sejak berdirinya tahun 1912 dikenal dengan semangat pembaharuan (tajdid) dengan slogan kembali kepada Al-Quran dan As-Sunnah, dalam kegiatannya hampir tidak bisa terpisahkan dari unsur perwakafan tanah,

\footnotetext{
${ }^{35}$ Wawancara dengan KH. Wahyu Afif (Pengurus Cabang NU Kota Bandung) pada hari senin tanggal 9 April 2018
} 
karena untuk mengurus harta benda wakaf dibentuk suatu majelis yang khusus menangani hal tersebut, yakni Majelis Wakaf dan Kehartabendaan. Berdasarkan hasil Muktamar ke-45 di Malang pada tahun 2005, nomenklatur tersebut diubah menjadi Majelis Wakaf dan Zakat Infaq dan Shadaqah (ZIS), dan kemudian disaat Muktamar Muhammadiyah ke-46 di Yogyakarta nomenklatur tersebut berubah kembali menjadi semula (Majelis Wakaf dan Kehartabendaan). ${ }^{36}$

Majelis Wakaf dan Kehartabendaan yang dibentuk berdasarkan Anggaran Dasar Muhammadiyah adalah: Organ Organisasi Pembantu Pimpinan, Majelis ini mempunyai tugas pokok untuk mengembangkan dan mengamankan harta wakaf dan harta kekayaan milik Persyarikatan serta membimbing masyarakat dalam melaksanakan wakaf, hibah, infaq dan shadaqah serta laiinya bersifat wakaf.

Selanjutnya pada jajaran organisasi tersebut, dibentuk pula Majelis Wakaf dan Kehartabendaan pada tiap-tiap Pimpinan Wilayah (Provinsi), Pimpinan Daerah (Kabupaten/Kota) dan Pimpinan Cabang (Kecamatan), yang masingmasing adalah Pembantu Pimpinan di Wilayah, daerah, dan Cabang, sekaligus kepanjangan tangan dari Majelis Wakaf dan Kehartabendaan Pimpinan Pusat Muhammadiyah.

Persyarikatan Muhammadiyah dalam surat Keputusan Dalam Negeri No. SK. 14/ DDA/1972 tentang Penunjukan Persyarikatan Muhammadiyah Sebagai Badan Hukum Yang Dapat Mempunyai Tanah Dengan Hak Milik.

Berdasarkan SK tersebut maka seluruh aset Persyarikatan Muhammadiyah diseluruh Indonesia baik wakaf atau pun non wakaf terdaftar harus atas nama Peryarikatan Muhammadiyah, walaupun yang menghimpun atau nazhir wakaf dapat dilakukan oleh Majelis Wakaf dan Kehartabendaan Wilayah, Daerah ataupun cabang di wilayah kerjanya masing-masing.
Perwakafan di Muhammadiyah memiliki peranan penting terhadap perkembangan Persyarikatan Muhammadiyah umumnya bagi umat Islam Indonesia, Persyarikatan Muhammadiyah berusaha memanfaatkan tanahtanah wakaf selain untuk sarana ibadah juga berusaha memanfaatkan tanah-tanah wakaf untuk sarana sosial

Muhammadiyah sebagai lembaga yang bergerak dibidang sosial keagamaan dikenal telah berhasil membantu program pemerintah khususnya dalam bidang pendidikan dan kesehatan serta ekonomi, Persyarikatan Muhammadiyah telah memiliki berbagai aset berupa sekolah, mulai dari tingkat Taman Kanakkanak (TK) hingga Perguruan Tinggi, serta Rumah Sakit yang tersebar diseluruh Indonesia. keberhasilan tersebut tidak luput dari perwakafan yang ada di Persyarikatan Muhammadiyah. ${ }^{37}$

\section{Visi dan Misi Majelis Wakaf dan Kehartabendaan}

Majelis Wakaf dan Kehartabendaan mempunyai visi yaitu:

Terlaksananya tugas persyarikatan amar ma'ruf nahi munkar yang berwibawa dengan cukupnya sarana dan prasarana, yang mandiri dalam persyarikatan muhammadiyah.

Sedangkan misinya adalah sebagai berikut:

1. Memantapkan kinerja Persyarikatan dengan konsolidasi organisasi diseluruh jajaran Muhammadiyah

2. Mendata kekayaan Persyarikatan dan menata pemanfaatan yang maksimal.

3. Menambah, menumbuhkan, mengembangkan dan mengamankan kekayaan Persyarikatan berupa wakaf dan kehartabendaan Muhammadiyah.

4. Meningkatkan keyakinan umat dalam melaksanakan amal wajib dan amal sunnah terutama dibidang zakat, infaq dan shadaqah.

\footnotetext{
${ }^{36}$ Wawancara dengan H. Acep Muharram T. Syamsudin, SH (Pengurus Muhammadiyah Kota Bandung) pada hari senin tanggal 17 April 2018

${ }^{37}$ http://wakaf.muhammadiyah.or.id/content-3-sdet-sejarah.html
} 
5. Meningkatkan penertiban administrasi dan motivasi beramal dalam Persyarikatan dengan peningkatan pengawasan diseluruh jajaran Muhammadiyah. ${ }^{38}$

\section{Kondisi Perwakafan Muhammadiyah Kota Bandung}

Perkembangan pengelolaan wakaf secara profesional ditandai dengan pemberdayaan potensi wakaf secara profesional produktif untuk kepentingan kesejahteraan umat manusia. Wakaf produktif adalah harta benda atau pokok tetapnya wakaf tidak secara langsung digunakan untuk mencapai tujuannya, tapi dikembangkan terlebih dahulu untuk menghasilkan sesuatu hasilnya disalurkan sesuai dengan tujuan wakaf. Seperti wakaf tanah untuk digunakan bercocok tanam, Mata air untuk dijual airnya dan lain-lain. Wakaf produktif juga dapat didefinisikan sebagai harta yang digunakan untuk kepentingan produksi baik dibidang pertanian, perindustrian, perdagangan dan jasa yang manfaatnya bukan pada benda wakaf secara langsung, tetapi dari keuntungan bersih dari hasil pengembangan wakaf yang diberikan kepada orang- orang yang berhak sesuai dangan tujuan wakaf.

Wakaf di Indonesia dikembangkan menjadi kelompok orang atau badan hukum yang diserahi tugas untuk memelihara dan mengurus benda wakaf. Yang di mana di cantumkan di dalam Pasal 9 UU No. 41 tahun 2004 tentang Wakaf menyebutkan bahwa Nazhir meliputi perseorangan; organisasi; atau badan hukum. Hubungannya dalam pengelolaan harta benda wakaf, maka Muhammadiyah sebagai organisasi keagamaan yang telah memperoleh status badan hukum telah menjalankan fungsinya sebagai nazhir. Status organisasi sebagai nazhir telah diakui Undang-Undang Nomor 41 Tahun 2004 tentang Wakaf, yaitu dengan memberikan kemungkinan suatu organisasi keagamaan bertindak sebagai nazhir harta benda wakaf.

Majelis Wakaf dan Kehartabendaan yang dibentuk berdasarkan Anggaran Dasar
Muhammadiyah adalah: Organ Organisasi Pembantu Pimpinan, Majelis ini mempunyai tugas pokok untuk mengembangkan dan mengamankan harta wakaf dan harta kekayaan milik persyarikatan serta membimbing masyarakat dalam melaksanakan wakaf, hibah, infaq dan shadaqah serta lainnya bersifat wakaf. Selanjutnya pada jajaran organisasi tersebut, dibentuk pula Majelis Wakaf dan Kehartabendaan pada tiaptiap pimpinan wilayah (Provinsi), pimpinan daerah (Kabupaten/Kota) dan pimpinan cabang (Kecamatan), yang masing-masing adalah pembantu pimpinan di wilayah, daerah, dan cabang, sekaligus kepanjangan tangan dari Majelis Wakaf dan Kehartabendaan Pimpinan Pusat Muhammadiyah. Perwakafan di Muhammadiyah memiliki peranan penting terhadap perkembangan Persyarikatan Muhammadiyah umumnya bagi umat Islam diseluruh Indonesia.

Mengacu kepada rakernas yang dilaksanakan pada 2 September hingga 4 September 2016, Majelis Wakaf dan Kehartabendaan (MWK) akan memprioritaskan gerakannya pada beberapa hal yaitu:

1. Pertama adalah sertifikasi tanah-tanah persyarikatan berikut aset-asetnya. Hal ini disebabkan karena sampai saat ini aset wakaf yang terdata baru hanya 25\%, selebihnya masih banyak tanah-tanah persyarikatan yang atas nama pribadi.

2. Inventarisasi aset wakaf. Langkah yang dilakukan adalah Pimpinan Pusat Muhammadiyah sudah menghimbau, mengirim surat, sosialisasi kepada Pimpinan Wilayah Muhammadiyah hingga Pimpinan Ranting Muhammadiyah agar memberikan data yang benar, sehingga data-data yang diterima oleh Pimpinan Pusat Muhammadiyah menjadi valid dan terpercaya juga tidak ada perbedaan-perbedaan data.

3. Pemberdayaan masyarakat. Dengan adanya banyak tanah wakaf dan aset yang menganggur, dikhawatirkan akan membuat muwakif kecewa.

\footnotetext{
38 http://wakaf.muhammadiyah.or.id/content-4-sdet-visi-dan-misi.html
} 
Karena yang diwakafkan tidak digunakan sehingga tidak bermanfaat.

4. Pendampingan aset-aset bermasalah. Langkah yang ditempuh adalah Pimpinan Pusat Muhammadiyah mendampingi Pimpinan Wilayah hingga Pimpinan Ranting untuk menyelesaikan persengketaan di pengadilan dari tingkat paling bawah hingga ke Mahkamah Agung. Pimpinan Pusat Muhammadiyah juga melibatkan para profesional dan praktisi dalam pendampingan ini. ${ }^{39}$

Pimpinan Daerah Muhammadiyah Kota Bandung berusaha memanfaatkan tanah-tanah wakaf selain untuk sarana ibadah juga untuk sarana sosial. Muhammadiyah sebagai lembaga yang bergerak di bidang sosial keagamaan dikenal telah berhasil membantu program pemerintah khususnya dalam bidang pendidikan dan kesehatan serta ekonomi, persyarikatan Muhammadiyah telah memiliki berbagai aset berupa sekolah, mulai dari tingkat taman kanakkanak (TK) hingga perguruan tinggi, serta rumah sakit yang tersebar di seluruh Indonesia.

Dalam tata kelola aset wakaf Muhammadiyah memakai mekanisme sentralisasi. Dengan kata lain aset-aset wakaf yang banyak terdapat di berbagai daerah dikelola oleh lembaga, sehingga kemanfaatannya dapat terukur secara matematis. ${ }^{40}$

Muhammadiyah sebagai organisasi keagamaan yang diakui oleh Undang-Undang No 41 tahun 2004 sebagai nazhir organisasi, memiliki organisasi pembantu pimpinan yaitu ialah majelis wakaf dan kehartabendaan dengan mengemban tugas pokok untuk mengembangkan dan mengamankan harta wakaf dan harta kekayaan milik persyarikatan. Majelis inilah yang sangat berperan dalam pemeliharaan, pengelolaan dan pengembangan wakaf.

\section{Model Nazhir Wakaf Profesional di Indonesia}

Kehadiran nazhir sebagai pihak yang diberikan kepercayaan dalam pengelolaan harta wakaf sangatlah penting. Walaupun para mujtahid sepakat tidak menjadikan nazhir sebagai salah satu rukun wakaf, namun para ulama sepakat bahwa wakif harus menunjuk nazhir wakaf, baik yang bersifat perseorangan maupun kelembagaan (badan hukum). ${ }^{41}$

Sebagai nazhir harus memenuhi beberapa syarat sehingga nantinya diharapkan mampu melaksanakan tugas dan kewajibannya dalam mengelola wakaf dengan maksimal dan optimal sesuai dengan harapan para wakif secara khusus dan kaum muslimin secara umum. Sehingga pengalaman-pengalaman pengelolaan harta wakaf yang tidak produktif seperti yang terjadi pada masa lalu tidak terulang lagi.

Para fuqaha tidak mencantumkan nazhir wakaf sebagai salah satu rukun wakaf, hal ini mungkin karena mereka berpendapat bahwa wakaf merupakan ibadah tabarru' (pemberian yang bersifat sunah saja). Padahal dalam pelaksanaan wakaf yang dilaksanakan di mana saja, kedudukan nazhir merupakan suatu hal yang sangat penting dan sentral. Di pundak nazhir inilah tanggung jawab untuk memelihara, menjaga, dan mengembangkan wakaf agar wakaf dapat berfungsi sebagaimana yang diharapkan. Nazhir inilah yang bertugas untuk menyalurkan hasil wakaf dan memanfaatkannya untuk kepentingan masyarakat sesuai yang direncanakan.

Sudah terlalu banyak pengelolaan harta wakaf yang dikelola oleh nazhir yang tidak profesional, sehingga banyak harta wakaf tidak berfungsi secara maksimal dan tidak memberi manfaat sama sekali sebagaimana yang diharapkan, bahkan banyak harta wakaf yang alih fungsi atau terjual kepada pihak-pihak yang tidak bertanggung

\footnotetext{
${ }^{39}$ Wawancara dengan H. Edi (Pengurus Muhammadiyah Kota Bandung) pada tanggal 27 April 2018

${ }^{40}$ Wawancara dengan H. Edi , (Pengurus Muhammadiyah Kota Bandung) pada tanggal 27 April 2018

${ }^{41}$ Paradigma Baru Wakaf di Indonesia,............, h.116
} 
jawab karena nazhir yang tidak dapat mengelola harta wakaf secara profesional. Untuk itulah diperlukan profesionalisme nazhir yang andal dan mempunyai keahlian dalam memanage benda wakaf secara baik dan benar. Syarat-syarat nazhir yang tersebut dalam kitab-kitab fikih kiranya perlu dipertahankan, yakni beragama islam, balig (dewasa), akil (berakal), memiliki kemampuan dalam mengelola wakaf (profesional), dan memiliki sifat amanah, jujur, tablig, dan fatanah serta adil. Syarat-syarat ini perlu ditingkatkan kemampuannya agar terwujud manajemen yang baik dalam pengelolaan wakaf. $^{42}$

Dengan pendekatan Total Quality Management (TQM), Achmad Djunaidi dkk. menjelaskan bahwa parameter nazhir professional adalah sebagai berikut: ${ }^{43}$

1. Amanah (dapat dipercaya)

2. Shidiq (jujur)

3. Fathanah (cerdas)

\section{Tabligh (transfaran)}

Sementara karakter sumber daya nazhir yang amanah adalah sebagai berikut: (1) terdidik dan tinggi moralitasnya, (2) memiliki keterampilan yang unggul dan berdaya saing, (3) memiliki kemampuan dalam melakukan pembagian kerja, (4) dapat melaksanakan kewajiban serta memperoleh hak yang adil, dan (5) memiliki standar operasional kerja yang jelas dan merata.

Syarat-syarat nazhir dalam peraturan perundang-undangan di Indonesia belum memasang "perangkap" agar harta benda wakaf dikelola sehingga berdaya guna secara maksimum karena tidak dicantumkannya persyaratan secara eksplisit kemampuan nazhir dari segi usaha-ekonomi. Oleh karena itu, gagasan Eri Sudewo mengenai syarat-syarat nazhir yang lebih dekat dengan semangat undang-undang nomor 41 tahun 2004 tentang wakaf, perlu diperhatikan.

\footnotetext{
${ }^{42}$ Abdul Manan, h. 269

${ }^{43}$ Djunaidi, Paradigma Baru, hlm. 82
}

Pada dasarnya siapapun dapat menjadi nazhir sepanjang ia bisa melakukan tindakan hukum. Akan tetapi karena tugas nazhir menyangkut harta benda yang manfaatnya harus disampaikan kepada pihak yang berhak menerimanya, jabatan nazhir harus diberikan kepada orang yang memang mampu menjalankan tugas tersebut. Untuk lebih jelasnya, persyaratan nazhir wakaf profesional itu dapat diungkapkan sebagai berikut:

1. Syarat moral, meliputi:

a. Paham tentang hukum wakaf dan ZIS, baik dalam tinjauan syari'ah maupun perundang-undangan negara RI.

b. Jujur, amanah dan adil sehingga dapat dipercaya dalam proses pengelolaan dan pentasharrufan kepada sasaran wakaf.

c. Tahan godaan, terutama menyangkut perkembangan usaha.

d. Pilihan, sungguh-sungguh dan suka tantangan.

e. Punya kecerdasan, baik emosional maupun spiritual.

2. Syarat manajemen, meliputi:

a. Mempunyai kapasitas dan kapabilitas yang baik dalam leadership.

b. Visioner.

c. Mempunyai kecerdasan yang baik secara intelektual, sosial dan pemberdayaan.

d. Profesional dalam bidang pengelolaan harta.

e. Ada masa bakti nazhir.

f. Memiliki program kerja yang jelas.

3. Syarat bisnis, meliputi:

a. Mempunyai keinginan.

b. Mempunyai pengalaman dan atau siap untuk dimagangkan. 


\section{c. Mempunyai ketajaman melihat peluang usaha sebagaimana layaknya entrepreneur. $^{44}$.}

Sebagaimana yang kita ketahui, inti yang terkandung dalam ajaran wakaf menghendaki agar harta wakaf tidak dibiarkan tanpa ada ahsil. Ini dikarenakan semakin banyak hasil harta wakaf yang dapat dinikmati orang, akan semakin besar pula pahala yang mengalir kepada wakif. Berdasarkan hal tersebut, pengembangan harta wakaf secara produktif merupakan kewajiban yang harus dilakukan oleh orang atau sekelompok orang yang istilah fikih wakaf disebut nazhir. ${ }^{45}$

Pada UU no. 41 Tahun 2004 Tentang Wakaf, dikatakan: "nazhir adalah pihak yang menerima harta benda wakaf dari Wakif untuk dikelola dan dikembangkan sessuai dengan peruntukannya."

Sesuai dengan fungsinya sebagai pengelola, maka harta benda wakaf yang didaftarkan oleh wakif harus atas nama nazhir. Terdaftarnya harta benda wakaf atas nama nazhir tidak menjadikan nazhir sebagai pemilik atas harta benda wakaf. Perlakuan tersebut untuk mempermudah nazhir dalam mengelola harta wakafnya. ${ }^{46}$

Dalam mengemban amanah sebagai nazhir, tentunya nazhir diharuskan memiliki beberapa kriteria khusus. Standar minimal yang harus dimiliki seorang nazhir, yaitu: beragama Islam, Mukallaf (memiliki kecakapan dalam melakukan perbuatan hukum), dan 'Aqil (berakal sehat), memiliki sifat amanah, jujur, dan adil serta memiliki kemampuan dalam mengelola wakaf (professional). ${ }^{47}$

Kemampuan yang dimiliki oleh seorang nazhir harus sesuai dengan harta wakaf yang akan dikelolanya sehingga tujuan kebermanfaatan harta wakaf dapat dirasakan secara maksimal di masyarakat. Misalnya bila nazhir ahli di bidang pertanian, maka nazhir dapat mengelola tanah wakaf sebagai cara menghasilkan produk pertanian. Demikian pula bila nazhir memiliki keahlian investasi, maka nazhir dapat mengelola investasi saham, reksadana, sukuk, logam mulia, maupun uang dari waqif untuk dikembangkan pada lembaga-lembaga keungan.

Semakin seorang nazhir memiliki keahlian khusus terhadap bidang yang ia geluti, semakin besar kemungkinan berkembangnya harta wakaf. Untuk itu, seseorang nazhir dituntut berpikiran luas dan senang mempelajari hal baru.

Lantas bagaimana bila seorang Nazhir tidak memiliki kemampuan khusus? Pada survey penelitian Rahmat Dahlan, dalam rangka meningkatkan kemampuan nazhir diperlukan sistem manajemen Sumber Daya Manusia (SDM) yang handal. Sistem tersebut bertujuan untuk: Pertama, meningkatkan dan mengembangkan pengetahuan kemampuan dan keterampilan para nazhir wakaf di semua tingkatan dalam rangka membangun kemampuan manajerial yang tangguh, professional dan bertangung jawab; kedua, membentuk sikap dan perilaku nazhir sesuai dengan posisi yang seharusnya, yaitu pemegang amanat umat Islam yang mempercayakan harta benda untuk dikelola secara baik dan pertanggungjawaban di hadapan Allah kelak; ketiga, menciptakan pola pikir atau persepsi yang sama dalam memahami dan menerapkan pola pengelolaan wakaf, baik dari segi peraturan perundang-undangan maupun teksin manajerial sehingga lebih mudah diadakan control, baik di daerah maupun pusat; keempat, mengajak para nazhir untuk memahami tata cara pengelolaan yang lebih berorientasi pada kepentingan Syariat Islam secara lebih luas dan dalam jangka panjang. Sehingga wakaf bisa dijadikan sebagai salah satu elemen penting dalam menunjang penerapan sistem ekonomi Syariah secara terpadu. ${ }^{48}$

\footnotetext{
${ }^{44}$ Ahmand Djunaidi, Panduan pemberdayaan tanah wakaf produktif strategis di Indonesia (Jakarta: Direktorat Pengembangan zakat Depag RI. 2005), h. 38-39. Lihat Eri Sudewo dalam Wadjdy, Farid dan Mursyid,........., h.160

${ }^{45}$ Murtadho Ridwan, Nazhir Profesional Kunci Kesuksesan Wakaf Produktif, dalam Jurnal Muqtashid, Vol. 3 No. 1 Juli 2012 , hal 99

${ }^{46}$ Pasal 3 Peraturan Pemerintah No. 42 Tahun 2006 Tentang Pelaksanaan Undang-Undang No. 41 Tahun 2004 tentang Wakaf.

${ }^{47}$ Nurodin Usman, Kompetensi Nazhir Dalam Mengelola Wakaf Produktif.........., h. 203

${ }^{48}$ Rahmad Dahlan, "Faktor-faktor yang memperngaruhi Presepsi Nazhir terhadap Wakaf Uang" dalam al-Iqtishad, Vol. VI No. 2, Juli 2014, hal. 306
} 
Setelah diketahui persyaratan minimal seorang nazhir dan tujuan diperlukan upaya pembinaan agar mereka dapat menjalani tugastugas kenazhiran secara prduktif dan berkualitas. Upaya pembinaan ini harus dilakukan berdasarkan standar pola manajemen terkini, antara lain:

Partama, pendidikan formal. Melalui sekolahsekolah umum dan kejuruan dapat dicetak caloncalon SDM kenazhiran yang siap pakai, dengan catatan sekolah itu sendiri harus dibentuk secara berkualitas dengan memberikan format kurikulum yang mantap dengan disiplin pengajaran yang tinggi, terarah menurut bidang yang dituju. Misalnya, sekolah menengah pertanian maupun tingkat perguruan tinggi yang diharapkan dapat mengelola tanah-tanah wakaf berupa persawahan, perkebunan, ladang pembibitan dan lain-lain.

Kedua, pendidikan non formal. Bentuk dari pendidikan model ini adalah dengan mengadakan kursus-kursus atau pelatihan-pelatihan SDM kenazhiran baik yang terkait dengan manajerial organisasi atau meningkatkan keterampilan dalam bidang profesi seperti administrasi, teknik pengelolaan pertanian, teknik perbankan, pengelolaan kepariwisataan, perdagangan, pemasaran dan lain sebagaina;

Ketiga, pendidikan informal. Berupa latihanlatihan dan kaderisasi langsung di tempat-tempat pengelolaan benda wakaf. Nazhir yang telah ada, ditingkatkan kemampuannya melalui latihanlatihan yang instensif dan bimbingan yang membuatnya kian maju dan mampu dalam bidang tugas dan tanggung jawabnya. Medan kerja itu sendiri menjadi "sekolah" dan taman belajar yang lebih praktis yang terkadang bobot dan mutunya lebih mantap dibandingkan dengan sekolah atau kursus.

Keempat, pembinaan mental. Spirit kerja harus terus menerus dibina agar para pemegang amanah perwakafan senantiasa bergairah dalam melaksanakan pekerjaannya. Demikian juga pembinaan mental budi pekerti (akhlak) yang luhur dibina melalui berbagai kesempatan seperti ceramah-ceramah agama, outbond, simulasi pengembangan diri dan organisasi untuk menjaga dan meingkatkan ketahanan mental supaya SDM kenazhiran bisa mengemban amanat untuk kesejahteraan nazhir banyak. ${ }^{49}$

Untuk mewujudkan hal tersebut, nazhir dapat bekerjasama dengan Badan Wakaf Indonesia yang memiliki kewajiban membina para Nazhir di seluruh Indonesia. Pembinaan tersebut dapat berupa pelatihan maupun seminar wakaf. Dengan demikian keterampilan Nazhir dapat mumpuni.

Pada hakikatnya, kedudukan nazhir sama dengan kedudukan pekerja sosial yang bekerja secara profesional untuk melaksanakan tugastugasnya untuk mengelola dan mengembangkan harta benda wakaf sesuai dengan peruntukannya sehingga berdampak memberikan kesejahteraan sosial. Pandangan ini berlawanan dengan referensi fiqih klasik, yang menyatakan bahwa peranan nazhir tidak begitu dianggap penting dan tidak termasuk salah satu rukun wakaf. Namun melihat tujuan dan kecenderungan pengembangan serta pemberdayaan wakaf yang diintensifkan saat ini, sudah saatnya nazhir ini mendapatkan perhatian khusus dan lebih bahkan sudah saatnya dimasukkan ke dalam salah satu rukun wakaf.

Mengenai kewajiban dan hak nazhir yang lebih diperjelas, termasuk sanksi yang diberikan apabila ada pelanggaran dalam pelaksanaan tugas tersebut. Dalam padal 42 UU Wakaf dijelaskan bahwa nazhir berkewajiban mengelola dan mengembangkan harta benda wakaf sesuai dengan tujuan, fungsi, dan peruntukannya, dan pada pasal selanjutnya ditekankan bahwa pengelolaan tersebut harus sesuai dengan ketentuan syariah dan dilakukan secara produktif, bahkan bilamana diperlukan lembaga penjamin, juga diperknakan asalkan lembaga penjamin tersebut juga yang berdasar syariah. Disamping itu, nazhir juga harus melakukan pengadministrasian, mengawasi dan melindungi harta benda wakaf, serta melaporkan pelaksanaan tugasnya kepada BWI.

$$
{ }^{49} \text { Ibid }
$$


Atas tugas-tugasnya tersebut, nazhir dapat menerima imbalan sebagai haknya, sebagaimana yang disebutkan dalam pasal 12 UU Wakaf, bahwa "nazhir dapat menerima imbalan dari hasil bersih atas pengelolaan dan pengembangan harta benda wakaf yang besarnya tidak melebihi 10\% (sepuluh persen)." Masalah imbalan bagi pera nazhir ini menimbulkan beberapa pertanyaan yang menggelitik, bagaimana bila harta wakaf yang dikelola oleh para nazhir tersebut belum produktif atau belum menghasilkan keuntungan? Pertanyan selanjutnya, dari manakah sumber pendanaan untuk membayar imbalan jasa nazhir yang mempunyai tugas untuk meningkatkan pengelolaan wakaf menjadi wakaf produktif? Lantas, apakah keprofesionalan seorang nazhir akan berubah kedudukannya dari pekerja sosial professional menjadi relawan sosial yang bekerja atas kehendaknya sendiri dan tanpa mengharapkan imbalan?. Pertanyaan-pertanyaan tersebut menjadi permasalahan tersendiri yang terjadi dalam pelaksanaan wakaf.

Dari hasil wawancara dengan narasumber, didapat bahwa kebanyakan nazir yang bertugas menjaga dan memelihara harta wakaf hanya berkedudukan sebagai relawan (volunter), artinya terhadap kegiatannnya tersebut nazhir tidak mendapat upah yang diberikan secara berkala sebagai bentuk imbalan jasa atau kewajibannya tersebut. Data lapangan juga menunjukkan bahwa tidak ada ketentuan yang mengatur batasan minimum wilayah kerja atas tugasnya sebagai nazhir, artinya seorang nazhir bisa memiliki tugas dan tanggung jawab mengelola tanah wakaf di beberapa lokasi wakaf. Sehingga memberikan kesan, bahwa nazhir tidak mungkin menjalankan tugas besarnya mengelola tanah wakaf secara maksimal bila ia memiliki beberapa objek wakaf yang harus dikelola secara produktif. Maka keberadaan pengaturan mengenai batas minimum seorang nazhir menjalankan profesionalitasnya harus ditetapkan, ini dibutuhkan untuk menjaga eksistensi kenazhiran yang diembannya.
Prof. Dr. Fathurrahman Djamil, ${ }^{50}$ mengatakan ada persyaratan umum lain bagi seorang nazhir, antara lain:

1. Nazhir adalah pemimpin umum dalam wakaf. Oleh karena itu nazhir harus berakhlak mulia, amanah, berpengalaman, menguasai ilmu administrasi dan keuangan yang dianggap perlu untuk melaksanakan tugas-tugasnya sesuai dengan jenis wakaf dan tujuannnya.

2. Nazhir bisa bekerja selama masa kerjanya dalam batasan undang-undang wakaf sesuai dengan keputusan organisasi sosial dan dewan pengeurus. Nazhir mengerjakan tugas harian yang menurutnya baik dan menentukan petugas-petugasnya, serta punya komitmen untuk menjaga keutuhan harta wakaf, meningkatkan pendapatannya, menyalurkan manfaatnya. Nazhir juga menjadi utusan atas nama wakaf terhadap pihak lain ataupun di depan mahkamah (pengadilan).

3. Nazhir harus tunduk kepada pengawasan Kementerian Agama dan Badan Wakaf Indonesia (BWI), dan memberikan laporan keuangan dan administrasi setiap seperempat tahun minimal, tentang wakaf dan kegiatannya;

4. Nazhir bertanggung jawab secara pribadi atas kerugian atau hutang yang timbul dan bertentangan dengan undang-undang wakaf.

\section{E. Penutup}

Nazhir wakaf telah diatur dalam Undangundang No. 41 Tahun 2004 tentang wakaf dengan sangat rinci, yaitu terdapat pada Bab II bagian ke-5, mulai pasal 9 sampai 14 . Sedangkan dalam konteks pengelolaan dan pengembangan benda wakaf diatur dalam Bab V mulai pasal 42 samoai 46. Hal demikian menunjukkan bahwa nazhir memiliki kedudukan yang signifikan di dalam Undang-Undang tersebut. Di samping itu, dapat dipahami bahwa eksistensi wakaf dan

\footnotetext{
${ }^{50}$ www.bwi.or.id
} 
pemberdayaannya sangat tergantung pada nazhir. Atau dengan kata lain, jika ada harta wakaf yang tidak produktif, atau harta wakaf yang hilang atau yang dialihkan, maka akar muaranya adalah pada nazhir yang kurang mampu menjalankan fungsinya dengan baik.

Dalam mengimplementasikan konsep nazhir wakaf profesional yang mengacu pada Undangundang perwakafan di Indonesia, NU sebagai organisasi masyarakat Islam terbesar membentuk lembaga yang menangani khusus tentang perwakafan dan pertanahan yaitu Lembaga Wakaf dan Pertanahan (LWP NU). Adapun aset-aset wakaf yang dimiliki oleh NU kota Bandung tersebar dalam bentuk yaitu: (1) Pondok pesantren, (2) Lembaga pendidikan, (3), Masjid, (4) Panti asuhan.
Sedangkan Muhammadiyah dalam mengimplementasikan konsep nazhir wakaf profesional membentuk Majelis Wakaf dan Kehartabendaan (MWK). Adapun aset-aset wakaf yang dimiliki oleh Muhammadiyah kota Bandung tersebar dalam bentuk sekolah, mulai dari tingkat taman kanak-kanak (TK) hingga perguruan tinggi, serta rumah sakit yang tersebar di seluruh Indonesia. Sebagian kecil lainnya adalah pondok pesantren, masjid dan panti asuhan.

Prospek nazhir wakaf profesional sangat lah penting, terutama dalam pengelolaan harta wakaf. Sehingga jika harta wakaf ingin produktif, maka tidak ada pilihan lain kecuali dengan membentuk nazhir yang profesional. Nazhir yang bukan hanya sebagai status, melainkan sebagai profesi yang menuntut kemampuan managerial, integritas moral yang kuat dan visi yang kuat. 


\section{Daftar Pustaka}

\section{Buku dan Jurnal:}

Abdul Gani Abdullah, Pengantar Kompilasi Hukum Islam dalam Tata Hukum Indonesia, Cet. 1, (Jakarta: Gema Insani Press, 1994).

Abdurrahman ibn Sa'd ibn 'Ali al-Syatsri, Hukm Taqnin al-Syari'ah al-Islamiyah, (Riyadh: Dar alhami'i li al-Nasyri wa al-Tausi'i, $1428 \mathrm{H}$ ).

Abdul Ghafur. Hukum dan Praktik Perwakafan. (Yogyakarta: Pilar Media. 2005).

Ahmad Djunaidi, Panduan pemberdayaan tanah wakaf produktif strategis di Indonesia (Jakarta: Direktorat Pengembangan Zakat Depag RI. 2005).

Ali Fikri, Al-Muamamalah al-Madiyah wal Adabiyah (Mesir: Musthafa al-Babial-Halabi, 1938).

Anwar Harjono, Hukum Islam Keluasan dan Keadilannya, (Jakarta: Bulan Bintang, 1968).

Anoname, Undang-undang Nomor 41 Tahun 2004 tentang Wakaf, Peraturan Pemerintah Nomor 42 Tahun 2006 tentang Pelaksanaannya, Peraturan Menteri Agama Nomor 4 Tahun 2009 tentang Administrasi Pendaftaran Wakaf Uang, (Jakarta: Dirjen Bimas Islam Depag RI, 2009).

Anoname, Panduan Wakaf, (Jakarta: Majelis Wakaf dan ZIS PP. Muhammadiyah, 2010).

Atjep Djazuli, Hifzh al-Ummah: Tujuan Hukum Islam, pidato penerimaan gelar doktor Honoaris Causa (HC) pada Universitas Islam Negeri Sunan Gunung Djati Bandung, 2009. Imam Muslim, Shahih Muslim, Juz III, No.1631

(Beirut: Darul Kutub al-Alamiyah, 1991).

Imam Bukhari, Shahih Bukhari, Juz III, (Semarang: Toha Putra, 1981).

Jaih Mubarok, Hukum Islam, (Bandung: Benang Merah Press, 2006).

Juhaya S Praja, Teori Hukum dan Aplikasinya", (Bandung: Pustaka Setia, 2011).

Juhaya S Praja, Filsafat Hukum Islam, (Bandung: LPPM UNISBA, 1995).
Mohammad Daud Ali, Sistem Ekonomi Islam Zakat dan Wakaf, (Jakarta; UI Press, 1999).

Muhammad Ibn Idris as-Syafi'i, al-Umm Juz III, (Mesir: Maktabah Kuliyah al-Azhariyah. t.th).

Muhammad Al-Kabisi,. Masyrû'iyah AlWakf AlAhli wa Madza Al-Maslahah Fîhi. (Baghdad: Lembaga Riset dan Studi Kearaban, 2004).

Mundzir Qahaf, Sanadât Al-Ijârah, Al-Ma'had AlIslâmy li Al-Buhûts wa At-Tadrîb. (Kairo: Dar usSalam, 1995).

Mundzir Qahaf, Manajemen Wakaf Produktif. (Jakarta: Khalifa, 2008).

Murtadho Ridwan, Nazhir Profesional Kunci Kesuksesan Wakaf Produktif, dalam Jurnal Muqtashid, Vol. 3 No. 1 Juli 2012.

Musahadi HAM, Evolusi Konsep Sunnah; Implikasinya pada Perkembangan Hukum Islam, (Semarang: Aneka Ilmu, 2000).

Nasrul Arifin, Keberlakuan Hukum Islam; Telaah Adabtabilitas Hukum Keluarga Islam di Era Moderen, dalam jurnal "al-Tahrir", vol. 8 No. 1, Januari 2008.

Usman Nurodin, "Kompetensi Nazhir dalam Mengelola Wakaf Produktif" ,Jurnal Suchamdi," Eksistensi (Qabul) Penerimaan dalam Akad Wakaf", Jurnal Justitia Islamica, Vol. 9, No.2, 2012

Peter Mahmud Marzuki, Penelitian Hukum, (Jakarta: Kencana, 2011).

Rachmadi Usman, Hukum Perwakafan di Indonesia, (Jakarata: Sindar Grafika, 1997).

Rahmad Dahlan, "Faktor-faktor yang mempengaruhi Persepsi Nazhir terhadap Wakaf Uang” dalam alIqtishad, Vol. VI No. 2, Juli 2014.

Satjipto Rahardjo, Hukum Progresif, Hukum Yang Membebaskan, (Semarang: edisi perdana Majalah Hukum Progresif, UNDIP, 2005).

Suparman Usman. Hukum Perwakafan di Indonesia. (Menara Kudus: Darul Ulum Press, 1994).

Taqiyudin Abi Bakar Ibnu Muhammad al-Husaini al-Dimasqi, Kifayatul Akhyar fii Hall Gayat alIkhtishar, Juz I (Semarang: Toha Putra, t.th). 
Taufiq Hamami, Perwakafan Tanah dalam Politik Hukum Agraria Nasional, (Jakarta: Tatanusa, 2003).

Teungku Muhammad Hasbi ash-Shiddieqy, Falsafah Hukum Islam, (Semarang: Pustaka Rizki Putra, 2001).

Zainuddin bin Abdul Aziz, Fathul Muin Bisyarh Qurratu 'Ain, (Semarang: Toha Putra, 2000).

\section{Website}

http://bwi.or.id/index.php/artikel/740standarisasi-dan-profesionalisme-nazhir-diindonesia

h t t p s : / / id.wikipedia.org/wiki/ Nahdlatul_\%27Ulama\#Sejarah https://lwpnu.or.id/

http://www.muhammadiyah.or.id/id/content-50det-sejarah.html

http://wakaf.muhammadiyah.or.id/content-4sdet-visi-dan-misi.html

www.bimasislam.kemenag.go.id

\section{Wawancara:}

Wawancara dengan Pengurus Cabang NU Kota Bandung

Wawancara dengan Pengurus Muhammadiyah Kota Bandung 